\title{
GLACIAL FEATURES OF TANQUARY FIORD AND ADJOINING AREAS OF NORTHERN ELLESMERE ISLAND, N.W.T.
}

\author{
By G. Hattersley-Smith \\ (Geophysics Section, Defence Research Telecommunications Establishment, Shirley Bay, \\ Ottawa 4, Ontario, Canada)
}

\begin{abstract}
The results of the present study support the conclusion that the former ice cover of northern Ellesmere Island was very much more extensive than the present, although the age of maximum glaciation is not known. In the Tanquary Fiord area the conclusion is based on: bathymetric data indicating considerable overdeepening of the fiords; morphology of the main valleys; and the presence of moraines, erratics and glacial lake deposits at high levels. Tanquary Fiord became free of glacial ice at least 6500 years ago and peat was forming in the valleys by this time. A long period of river erosion followed the main retreat of the ice. Subsequently, and within the last 4 ooo years, glaciers advanced to re-occupy V-shaped valleys. and at the same time small ice caps were probably regenerated. In the last goo years, however, there has been little change in the terminal position of most of the major glaciers, which appear to be advancing slightly, although in the last 40 years the side glaciers have receded from well-marked terminal moraines.

RÉsumÉ. Caractéristiques glaciaires du Tanquary Fiord et des régions avoisinantes de l'Ellesmere Island nord, N.W.T. Les résultats de la présente étude amènent la conclusion suivante: la première couche de neige de l'Ellesmere Island nord, était beaucoup plus étendue qu'actuellement, bienque l'âge de la glaciation maximum ne soit pas connu. Dans la région du Tanquary Fiord, la conclusion est fondée sur: les données bathymétriques indiquant une augmentation de profondeur considérable et poussée des fiords; la morphologie des vallées principales; et la présence de moraines, dépôts de lacs glaciaires et ératiques sur les hauts plateaux. Le Tanquary Fiord se libéra des glaces il y a au moins 6500 ans et, à cette époque, de la tourbe se constitua dans les vallées. Une longue période d'érosion fluviale suivit la principale retraite glaciaire. Par la suite et au cours des derniers 4 ooo ans, les glaciers avancèrent pour réoccuper les vallées en $\mathrm{V}$ et au même moment, de petites calottes glaciaires furent probablement régénérées. Durant les derniers 9oo ans, il y eut cependant un léger changement dans la position terminale de la plupart des glaciers principaux qui paraissent avancer quelque peu bien que durant les 40 dernières années les glaciers sur les côtés s'éloignèrent des moraines terminales bien marquées.
\end{abstract}

Zusammenfassung. Glaziale Erscheinungen am Tanquary Fïrd und in den angrenzenden Gebieten des nördlichen Ellesmere Island, N.W.T. Die Ergebnisse der vorliegenden Untersuchung stützen die Annahme, dass die frühere Eisbedeckung des nördlichen Ellesmere Island weit ausgedehnter war als die gegenwärtige, obgleich die Zeit der stärksten Vergletscherung nicht bekannt ist. Im Gebiet des Tanquary Fiord gründet sich dieser Schluss auf folgende Beobachtungen: Lotungen, die eine beträchtliche Übertiefung der Fjorde anzeigen; die Morphologie der Haupttäler; das Vorhandensein von Moränen, Findlingen und glazialen Seeablagerungen in höheren Lagen. Der Tanquary Fiord wurde vor mindestens 6500 Jahren frei von Gletschereis; zu dieser Zeit bildete sich in den Tälern Torf. Auf den Hauptrückgang des Eises folgte eine lange Periode mit Flusserosion. Anschliessend und in den letzten 4 ooo Jahren stiessen Gletscher vor und erfüllten die V-Täler erneut. Zur gleichen Zeit regenerierten sich vermutlich kleine Eiskappen. In den letzten goo Jahren traten nur gleine Schwankungen in der Endlage der meisten Hauptgletscher ein, die derzeit anscheinend langsam vorrücken, obgleich in den letzten $40 \mathrm{Jahren}$ die Seitengletscher sich von ausgeprägten Endmoränen zurückgezogen haben.

\section{INTRODUCTION}

From previous work in northern Ellesmere Island it was concluded that the Quaternary glaciation produced an ice cover that was mainly protective in the plateau region south and south-west of Alert (Hattersley-Smith, I96 I [b]), while to the west the higher relief and greater pre-glacial dissection allowed the ice to be channelled in its outflow from the inland ice caps, with the result that great trunk glaciers were formed and the fiords were excavated out of the pre-existing river valleys (Hattersley-Smith, I96I[a]). It was pointed out that the Quaternary glaciation of northern Ellesmere Island can only be seen as a whole. Thus, although there was probably more than one glacial phase, there is no clear evidence of cyclic repetition. This is because critical material, in the form of moraines and glacial outwash deposits, was originally deposited off the shore, or has been removed from the valleys by subsequent glacial and river erosion. Nevertheless, on the north coast the overdeepened fiords, the truncated spurs at the sides of the fiords, and glacial striae at considerable altitudes justify the belief that the former 
ice cover was nearly complete. There were no doubt nunataks in the general ice cover, particularly in the higher parts of the area, for the glaciation was essentially of alpine rather than ice-sheet type.

Very widespread glaciation in the north coastal area was followed by an amelioration of climate. As the ice caps thinned and the glaciers receded, the land rebounded with release of glacial loading, and raised beaches were formed up to an altitude of at least $90 \mathrm{~m}$ above present sea-level (Christie, I 967 ). By the time of the Climatic Optimum, 4 ooo to 6 ooo years ago, there had been substantial withdrawal of glaciers from the coastal region. A deterioration

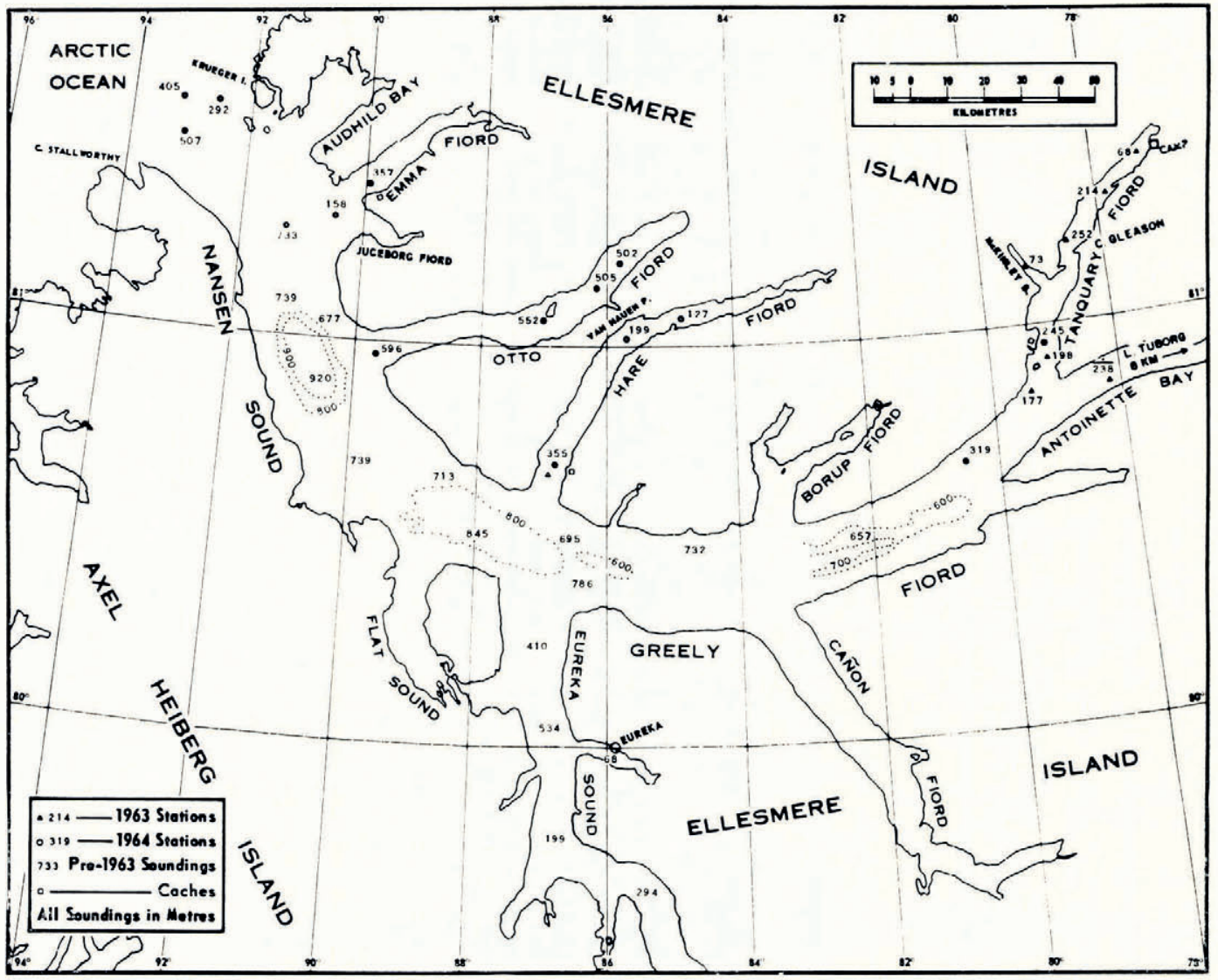

Fig. 1. Bathymetric map of the Nansen Sound fiord system, showing soundings taken from the ice by Defence Research Board field parties in 1963-64. Pre-1963 soundings are from reconnaissance surveys by the United States Coastguard (1.950), the U.S. Navy (1952) and the Canadian Hydrographic Service (1954-62). (Adapted from Chart No. 7077 of the Canadian Hydrographic Service.)

in climate, following the Climatic Optimum, was accompanied by the formation of ice shelves off the north coast, by the advance of glaciers onto raised beaches and into $\mathrm{V}$-shaped valleys, by the growth of low ice caps over raised beaches on exposed parts of the coast, and by the advance of piedmont glaciers into main valleys causing diversion of drainage (Crary, 1960; Hattersley-Smith, r96o).

Subsequent work by Lyons and Leavitt ( $196 \mathrm{r}$ ) confirmed the general validity of the above conclusions and added detail to the sequence of events in the area of Ward Hunt Island off the north coast. In the Lake Hazen area, Smith ( I96I) also inferred an earlier complete ice cover, 
with flow of ice predominantly from north to south, and Christie (1967) concluded that glacial features and deposits demonstrate a general outward movement of ice from the high mountains of northern Ellesmere Island with only a limited incursion of Greenland ice on the eastern shore.

The present paper is based on reconnaissance field work from Tanquary Camp, the Defence Research Board's field station at the head of Tanquary Fiord, since I963 (Figs. I and 2). The reconnaissance covered most of the ice-free area within a radius of $30 \mathrm{~km}$ of the camp and included traverses of the four main valleys that converge on the head of the fiord. Extended spring traverses for the main purpose of oceanographic work were made over the ice throughout Tanquary and Greely Fiords, and Nansen Sound, with digressions into Hare, Otto and Emma Fiords; bathymetric data were obtained on these traverses, together with

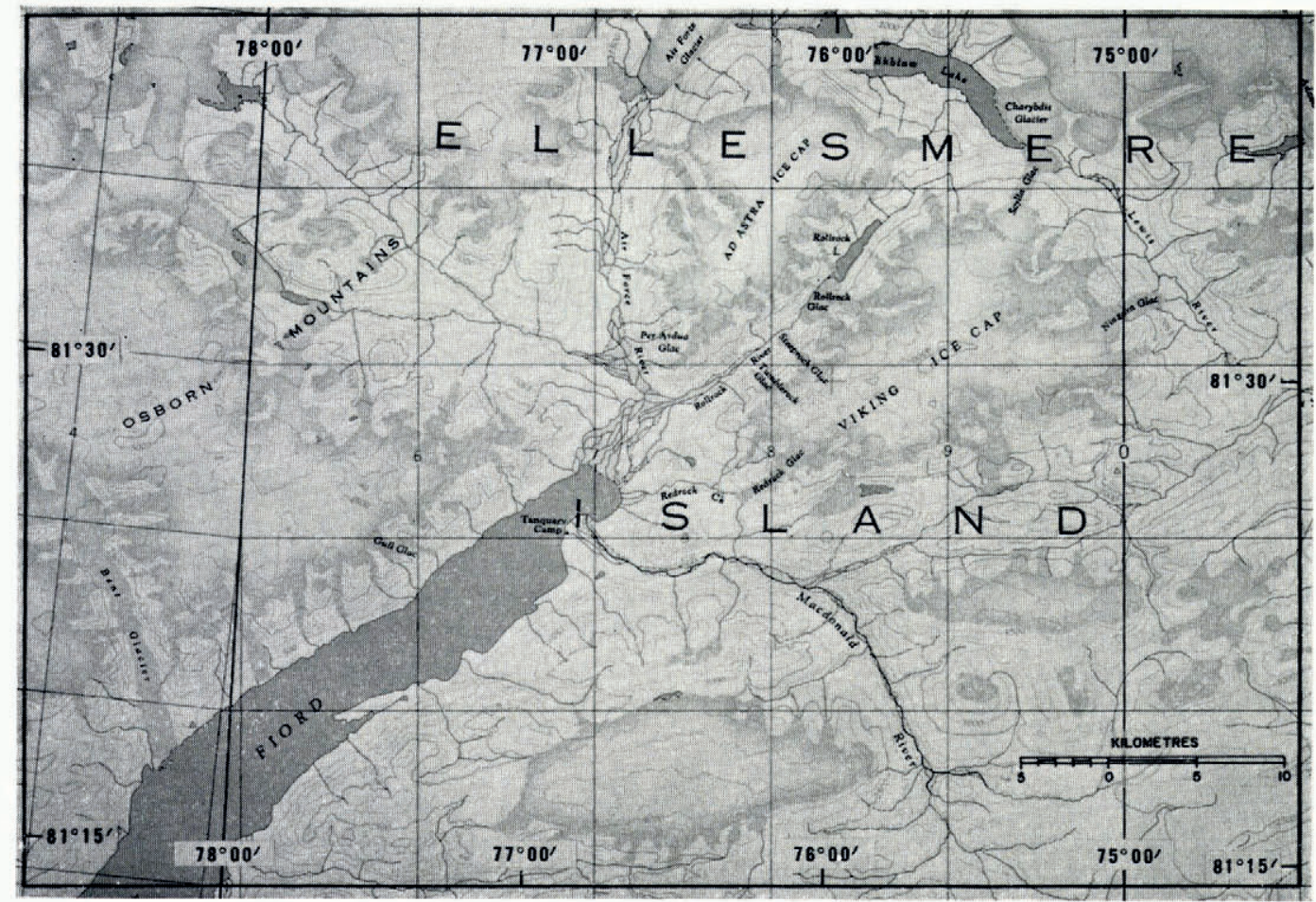

Fig. 2. Map of the Tanquary Fiord area. (Part of sheet No. 340-D published by the Surveys and Mapping Branch, Department of Energy, Mines and Resources, Canada.)

some information on glacial and shoreline morphology, although opportunities for work off the ice were restricted.

After a brief statement of the geological setting, first the fiords of north-western Ellesmere Island and then the main valleys at the head of Tanquary Fiord will be considered in order to show the extent of their modification by glaciers. Finally, from glacial features of the Tanquary Fiord area, radiocarbon ages of organic material and glaciological data, conclusions will be drawn on the course of deglaciation and on recent climatic trends in the area centred on Tanquary Fiord.

\section{Bedrogk Geology}

The following brief statement on the bedrock geology is based on information kindly provided by Dr R. L. Christie (Nassichuk and Christie, in press). In the Tanquary Fiord area, 
Upper Palaeozoic and Mesozoic rocks, deposited in the Sverdrup sedimentary basin, overlie Lower and Middle Palaeozoic strata of the Franklinian geosyncline. The pre-Carboniferous basement strata are represented by the Cape Rawson group of mainly impure sandstones, greywackes and shales, which are slightly metamorphosed and tightly folded, with the folds overturned to the south. The Cape Rawson strata, with a regional strike from east-north-east to west-south-west, are exposed over a very wide area about the head of the fiord. Uplift in the area in late Triassic time, bounded by major faults on the south-east at the head of the fiord and on the north-west at Yelverton Pass, led to much reduced thicknesses or absence of late Palaeozoic and early Triassic formations. Late Palaeozoic and Mesozoic formations are present only on the south-east side of the fiord; near the mouth and on the south side of the Macdonald valley; between the east side of the Rollrock valley and the Air Force valley; and near the head of the north-west valley. The rocks comprise limestone and sandstone of Carboniferous and Permian age, Triassic sandstone, Jurassic black shales and Lower Cretaceous sandstone. The scarp in Cape Rawson strata on the north-west side of the head of the fiord was produced by the south-eastern of the two major faults, which passes inland near the tongue of Bent Glacier. In contrast, Triassic sandstones, dipping at about $20^{\circ}$ to the north-north-west, are exposed along the south-east shore in the upper part of the fiord, overlying the Palaeozoic strata that are exposed about $6 \mathrm{~km}$ to the south-east. Basalt sills and dykes of considerable thickness and lateral extent are widespread in the Mesozoic formations, particularly in the Upper Triassic sandstone and the Cretaceous sandstone.

\section{Fiords of North-western Ellesmere Island, including Nansen Sound}

The probable development of Nansen Sound and the offlying fiords (Fig. I) from a Tertiary river system draining north-westward to the Arctic Ocean was recognized by Fortier and Morley (1956). The present paper is not concerned with the structural relations that controlled the course of such a river system, except to point out that the major north-west to south-east fault mentioned above controlled the course of the upper $25 \mathrm{~km}$ of Tanquary Fiord, and to suggest that faulting may have controlled the arcuate sweep of the generally cliffed coast from the mouth of Tanquary Fiord as far north as Jugeborg Fiord (cf. Thorsteinsson and Tozer, r96o, p. r8).

\section{Bathymetry}

Bathymetric data in the fiord system were obtained on cruises by U.S.C.G.C. Eastwind in 1950, by U.S.S. Edisto in Nansen Sound in 1962, and by C.C.G.S. Fohn A. Macdonald in Nansen Sound, Greely and Tanquary Fiords in 1962, and were supplemented by data obtained by Defence Research Board field parties in 1963 and 1964 (Fig. I).

Continuous track soundings down the centre of Tanquary Fiord and on a zig-zag course back and forth across the fiord over its length indicate the characteristics of a true fiord. The sill at the mouth is at a depth of about $165 \mathrm{~m}$ and the greatest depth measured within the fiord is $305 \mathrm{~m}$. In the upper $25 \mathrm{~km}$ of the fiord the bottom falls away more steeply on the north-west side where soundings indicate a submerged river channel. The fiord is overdeepened below sill depth throughout its length, except in the upper ro $\mathrm{km}$ and near the tongue of Bent Glacier (Fig. 2). In the latter area maximum depths are close to the sill depth; since Bent Glacier is the only tide-water glacier entering the fiord, it is suggested that deposition of moraine and glacial outwash have reduced the depths since the main withdrawal of glacier ice. It is also significant that the one deep basin within the fiord with depths below $275 \mathrm{~m}$ is centred down-fiord from the junction with McKinley Bay. This could have been caused by increased glacial scour where the trunk glacier thickened after junction with Chapman Glacier, which drains into McKinley Bay. The constriction and the curve downfiord should also have tended to increase the ice thickness. A relatively shallow sounding of 
$73 \mathrm{~m}$ half-way up McKinley Bay may possibly be due to infilling of this bay since the withdrawal of the ice.

The bathymetry of Greely Fiord is based on a single track of soundings more or less down the centre of the fiord (except opposite Cañon Fiord) and on a zig-zag track of soundings crossing the central section of the fiord. From the junction of Antoinette Bay with Tanquary Fiord depths increase rather irregularly from about $180 \mathrm{~m}$ to about $500 \mathrm{~m}$. Off the mouth of the unnamed fiord on the south side changes in bottom relief of up to $30 \mathrm{~m} / \mathrm{km}$ indicate an undulating sea floor. From here a central trough (Fig. I) is developed to a width of at least $4 \mathrm{~km}$ and with depths exceeding $600 \mathrm{~m}$, deepening to $700 \mathrm{~m}$ halfway between the unnamed fiord and Cañon Fiord. It seems likely, although there are no data for confirmation, that this trough is continuous into Nansen Sound, and that it widens considerably opposite the mouth of Cañon Fiord, as might be expected if formerly a large tributary glacier joined a Greely Fiord trunk glacier in this area. Soundings suggest that the sides of this trough have dips up to at least $12^{\circ}$, and that changes in relief of the sea floor of the order of $50 \mathrm{~m} / \mathrm{km}$ may occur within the trough. An $800 \mathrm{~m}$ deep basin is predicted off Cañon Fiord but soundings also indicate a medial rise at the mouth of Greely Fiord, where depths less than $600 \mathrm{~m}$ have been recorded.

A basin with depths below $800 \mathrm{~m}$, elongated parallel to the fiord, extends from due north of the east side of Eureka Sound to duc north of the west side of Flat Sound. It lies squarely across the mouth of Hare Fiord and is about $5^{\circ} \mathrm{km}$ long with an average width of about I I $\mathrm{km}$ (Fig. I). Side slopes for the basin are probably similar to those given for the trough. The basin occurs at the junction of the fiords and sounds where a great thickening of glacial ice could have occurred. North-west of Flat Sound, Nansen Sound widens and the basin shallows out, but the trough continues at depths below $700 \mathrm{~m}$ until opposite the south side of Otto Fiord (Fig. 3), where another deep basin starts with depths below $800 \mathrm{~m}$ and in the central part below $900 \mathrm{~m}$ (Fig. I). Again it is significant that the basin lies across the mouth of a large fiord. It is here that the greatest depths in Nansen Sound - a maximum of $920 \mathrm{~m}$ - have been measured. The existence of these basins in areas of confluence in the fiord system strongly points to glacial erosion as their cause. It is noted that depths of water in Nansen Sound are the greatest known within the Canadian Arctic Archipelago (De Leeuw, i 967 ).

For the area between Jugeborg Fiord and Cape Stallworthy no soundings are available, but the three soundings taken in 1964 across the mouth of Nansen Sound give no indication of a deep-water trough extending out into the Arctic Ocean. Admittedly, these soundings in themselves do not prove the non-existence of a narrow trough, but a comparison of oceanographic data from the ice island $\mathrm{T}_{3}$, when it drifted past this area in $\mathrm{I}_{955^{-}} 5^{6}$, with data taken in Nansen Sound from John A. Macdonald in r 962 makes the existence of a deep trough connexion with the Arctic Ocean very unlikely (Ford and Hattersley-Smith, I965). The same data are also incompatible with the presence of a shallow sill, below say $300 \mathrm{~m}$, across the mouth of Nansen Sound. The question of the existence of a deep buried channel at the mouth of Nansen Sound must remain open until seismic data are available. If such does not exist, the large amount of material glacially eroded from Nansen Sound must have been deposited out on the continental shelf or beyond. The depths of 400-500 $\mathrm{m}$ found in the mouth of Nansen Sound are in accordance with the depth of $450 \mathrm{~m}$ for the continental shelf found from work on $\mathrm{T}_{3}$ (Crary and Goldstein, 1957). The great width of Nansen Sound suggests drowning of the pre-glacial river valley to an unknown extent. In the case of the land bordering Peary Channel and the Prince Gustaf Adolf Sea, lying to the west of Axel Heiberg Island, recent submergence of at least $400 \mathrm{~m}$ is deduced by Pelletier (1966). As far as can be seen from the soundings, the cross-profile of Nansen Sound is broadly U-shaped; near land on the east side the bottom falls away at slopes up to at least $\mathrm{I}^{\circ}$. There is the possibility that much of the widening of Nansen Sound was accomplished by the lateral erosion of marginal glacial rivers. 
The great depths in Otto Fiord are seen as the result of erosion by Otto Glacier at the head of the fiord, the main western outlet of the extensive ice cap lying north-west of Tanquary Fiord and one of the most active glaciers in northern Ellesmere Island at the present time. Exceptional activity by this glacier in the past may reasonably be inferred. Flowing down from an elevation of $\mathrm{I} 800 \mathrm{~m}$ above sea-level in a straight valley $35 \mathrm{~km}$ long and $4^{-6} \mathrm{~km}$ wide, the glacier made a spectacular $3 \mathrm{~km}$ advance between $195^{\circ}$ and 1959 , as recorded by air

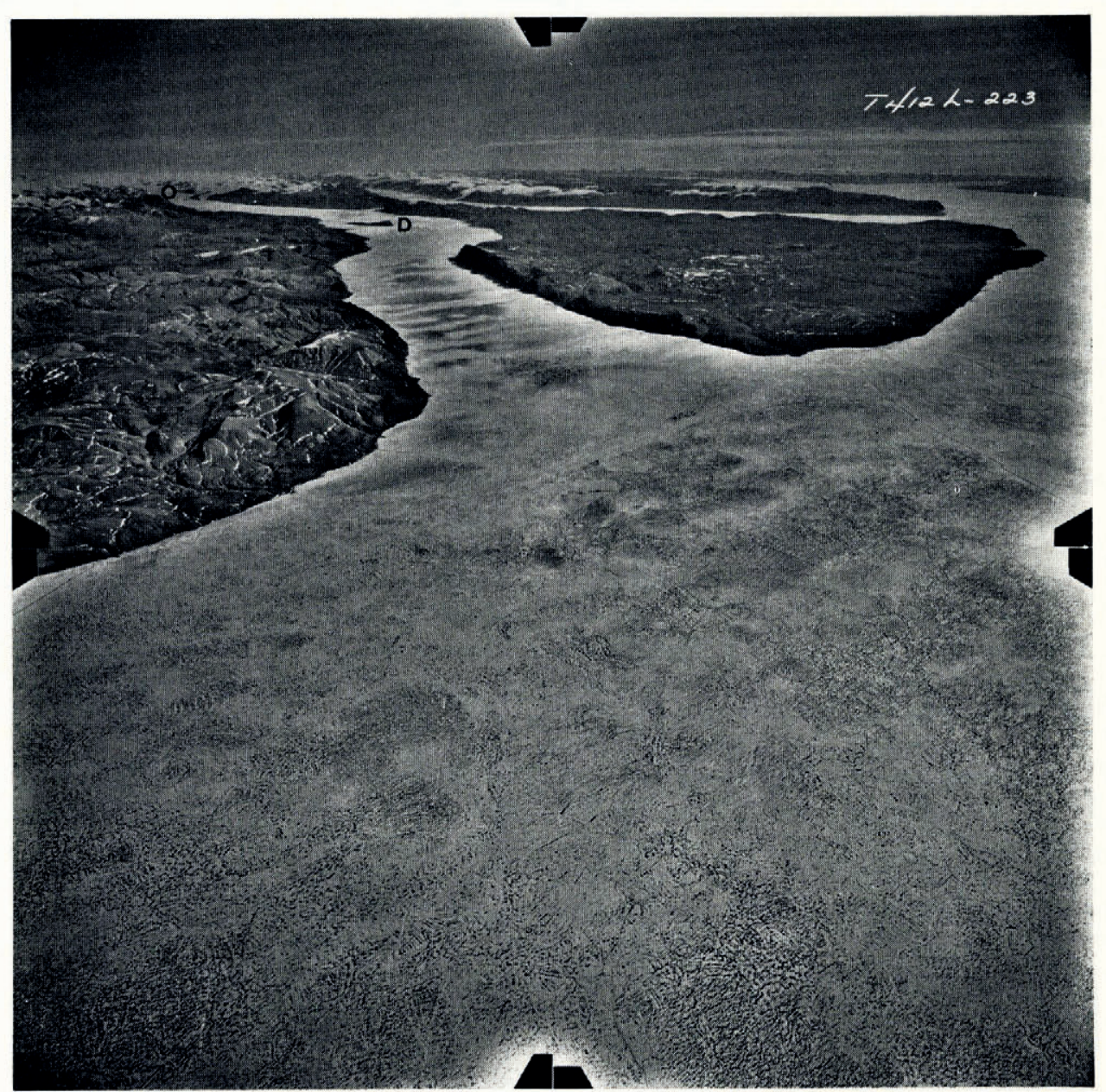

Fig. 3. Nansen Sound and Otto Fiord from the north-west, showing Degerbols Island $(D)$ and Otto Glacier $(O)$. Oblique air photograph $T_{412 L-223}$ from $6095 \mathrm{~m}, 16$ July 1950. (Courtesy of National Air Phot graphic Library, Department of Energy, Mines and Resources, Canada.)

photographs in those years (Hattersley-Smith, 1964), and a continuing surge of $2 \mathrm{~km}$ between I959 and I964 (Konecny, I966). With the great depths of water far up the fiord-502 $\mathrm{m}$ within $12 \mathrm{~km}$ of the present ice front-it seems likely that a small initial advance of the glacier from whatever cause was sufficient to trigger the sudden surge, as the glacier became free to float off, thereby reducing the sliding friction at the base of the glacier to zəro. This implies fiord depths of about $300 \mathrm{~m}$ almost up to the $195^{\circ}$ position of the glacier terminus. The many icebergs resulting from the surge are thickly congregated in the upper part of the fiord; very 
few have drifted down-fiord past Degerbols Island (Fig. 3). The existence of a sill at the mouth of Otto Fiord must remain in doubt, although a single sounding in the middle here showed almost $600 \mathrm{~m}$ of water. The depths found in Hare Fiord are from 150 to $200 \mathrm{~m}$ less than at corresponding points in Otto Fiord, and are also one-half to two-thirds those at corresponding points over the length of Tanquary Fiord. This may be attributed to the fact that Hare Fiord is unfavourably oriented to channel glacial drainage from the ice caps.

\section{Surface features}

While the submarine morphology of the fiords constitutes the strongest evidence for the passage of large glaciers and widespread glaciation in the Greely Fiord-Nansen Sound area, surface features lead to the same general conclusion. The latter evidence is limited at present, although much more will no doubt come to light.

In the upper part of Tanquary Fiord occupation by massive glaciers is clearly indicated by at least one major surface feature. The south-east side of the fiord, rising steeply but fairly smoothly to a rolling plateau 600 to I $200 \mathrm{~m}$ above sea-level, has been moulded by a glacier moving down-fiord from the direction of the Macdonald valley (Fig. 2). The glacier scoured a gently sloping bench about $300 \mathrm{~m}$ wide, extending from $3 \mathrm{~km}$ south of Tanquary Camp to a point about $5 \mathrm{~km}$ south-west of Fishhook Point; it starts at an elevation of about $35^{\circ} \mathrm{m}$ and fades out at an elevation of about $60 \mathrm{~m}$ above sea-level (Fig. 4). Immediately below the bench, the slope of the hillside is convex, then becomes concave at a maximum angle of about $40^{\circ}$. The bench is cut by the streams of seven ravines, only two of which are glacier-fed, but all of which are presumed to have been initiated or rejuvenated by the withdrawal of ice from the fiord and the melting of ice caps to the south-east. In a distance of about $7 \mathrm{~km}$ between the bench and the present ice caps, a series of valleys and depressions trending parallel to the fiord up to an elevation of about $800 \mathrm{~m}$ mark the course of marginal drainage channels, which were formed as the level of glacier ice in the fiord subsided; several of them still carry streams. Erratic material at the surface of the grey Triassic sandstone in this area includes: grey limestone, maroon sandstone, basalt and black phyllite, all from rocks not very far distant. It was observed that surface material up to an elevation of at least $250 \mathrm{~m}$ consisted of subangular pebbles and cobbles, indicating as might be expected re-working of morainic material by glacial streams.

If account is taken of water depths up to $200 \mathrm{~m}$ in the upper part of Tanquary Fiord, the available evidence suggests a former glacier up to $\mathrm{I}$ ooo $\mathrm{m}$ in thickness moving down from the head of the fiord. If other glaciers in western Ellesmere Island were of similar proportions in Pleistocene time, erratic material far-travelled from the east could be expected on the shores of Nansen and Eureka Sounds. Previous reports of such material have come from Schei Peninsula and Stor Island. In the former locality, situated on Axel Heiberg Island directly opposite the mouth of Greely Fiord, Rudberg ( 1963 ) reported erratics up to an elevation of $400 \mathrm{~m}$ resting on gabbro bedrock striated from the south. He deduced an extensive invasion by ice from a centre outside Axel Heiberg Island. On Stor Island, Troelsen (1952) deduced that at one time the whole Eureka Sound area was under an ice cover that had its centre or centres in eastern Ellesmere Island. Tozer (Fortier and others, I963) assumed that Troelsen based his conclusion on the occurrence of rounded boulders of gneiss, granite and quartzite on the upland surface of eastern Stor Island up to an elevation of over $300 \mathrm{~m}$ and on their interpretation as of morainic origin. However, Tozer did not exclude the possibility of the material being ice-rafted. Farther north near the southern point of the entrance to Otto Fiord (Fig. 3), the present writer found evidence of strong glaciation on the now completely ice-free peninsula between Otto and Hare Fiords. The $125 \mathrm{~m}$ high hill near the point is liberally covered with till and glacial outwash to its summit, and the $175 \mathrm{~m}$ hill $\mathrm{I} \mathrm{km}$ to the east also carries till and glacial outwash to its summit, displaying rounded kame-like forms. Farther east again, up to a height of nearly $300 \mathrm{~m}$ sub-angular boulders, shingle and outwash 
gravel occur. On the plateau near the top of the high vertical cliffs south of the point, at an elevation of $355 \mathrm{~m}$, gabbro and red sandstone erratics were found, together with occasional water-worn cobbles and boulders. These deposits indicate extensive glaciation such as would be associated with glaciers occupying Nansen Sound and Otto Fiord, and with a complete ice cover on the peninsula.

From the radiocarbon age of a shell sample, collected by the author at an elevation of $55^{-} 5^{8} \mathrm{~m}$ above sea-level at the head of Tanquary Fiord (GSC-373; Lowdon and others, I 967 , p. I94), it is known that the fiord was clear of glacial ice by at least 6500 years ago.

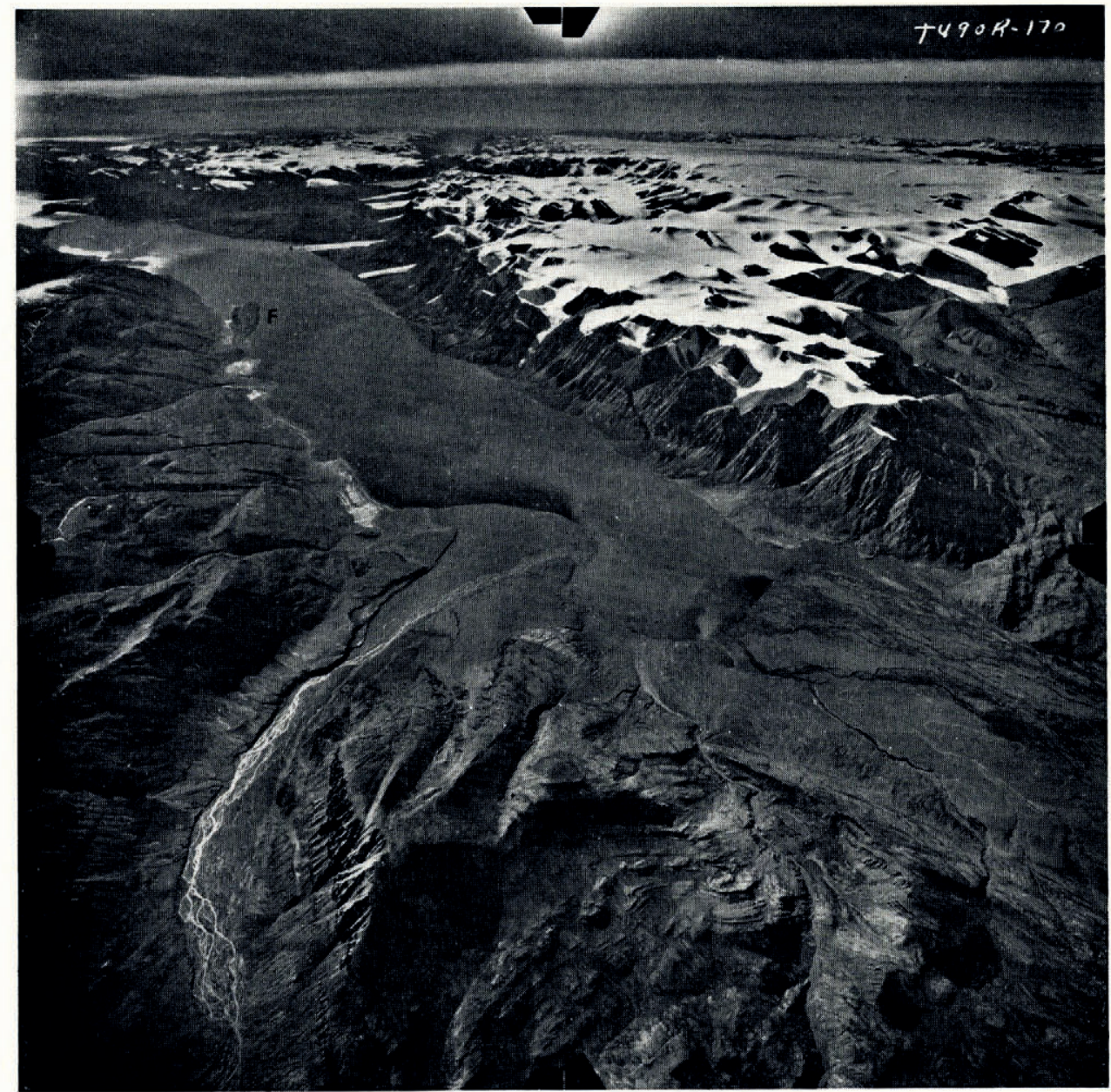

Fig. 4. Head of Tanquary Fiord from the north-east (Fishhook Point, F). Oblique air photograph $T_{490 R-170}$ from 6 og5 $\mathrm{m}$, 28 7uly 1952. (Courtesy of National Air Photographic Library, Department of Energy, Mines and Resources, Canada.)

\section{Valleys at the Head of Tanquary Fiord}

There are four main valleys converging on Tanquary Fiord (Fig. 2): from the north-west (referred to as the north-west valley), north (Air Force valley), north-east (Rollrock valley) and east (Macdonald valley). With the exception of Air Force valley, which drains the central ice cap of northern Ellesmere Island, all these valleys are predominantly ice-free right up to the divides, although along their sides glaciers debouch from ice caps and in two cases have 
moved across valleys. The profiles of all these valleys throughout their length are markedly U-shaped, except for the upper part of Macdonald valley, which is box-shaped; the typical profile is in contrast to the $\mathrm{V}$-shaped profiles of most tributary valleys in the area, and of valleys far-removed from the main ice cover of northern Ellesmere Island, and to the V-shaped profiles reported from Axel Heiberg Island (Souther in Fortier and others, 1963; Rudberg, I963). In certain respects the morphologies of the four valleys differ but all have been modified by the passage of great thicknesses of ice. At the same time there are well-developed cirques in the area, especially the cirque that forms the basin of Per Ardua Glacier. To what extent we are viewing in the present landscape the effects of Wisconsin glaciation or of an earlier glaciation is a matter for speculation.

\section{North-west valley}

If we ignore deep incision by the river, especially in its lower course, the profiles of the north-west valley and its tributary arm are classically U-shaped with truncated spurs, and the main valley can be said to hang at an elevation of approximately $275 \mathrm{~m}$ above the floor of Air Force valley (Fig. 5). The recent lowering of sea-level by at least $60 \mathrm{~m}$ (Hattersley-Smith and Long, 1967) accounts for the incised lower course.

The U-shaped upper profile of the main arm of the north-west valley rises very gradually from an elevation of $275 \mathrm{~m}$ at the mouth to $55^{\circ} \mathrm{m}$ near the divide, where Yelverton Lake, about $3 \mathrm{~km}^{2}$ in area, is marginal to a large outlet glacier flowing north into Yelverton Inlet. On the north-east side of the river, down-stream from the main fork, the surface is liberally covered with till and local bedrock detritus between outwash fans from the valleys below cirque glaciers. There are also irregular kame-like deposits of sub-rounded boulders and gravel. Signs of former glacial marginal channels are absent on this side of the valley, but on the south-west side, where the slopes are also mantled by till and outwash deposits, the structure of the east-west striking and steeply dipping Cape Rawson beds has been emphasized by the work of marginal channels on the glacial bench that extends out over the Air Force River. On both sides of the valley, glaciers have advanced into V-shaped valleys, which suggests a long period of fluvial erosion following the main retreat of the ice and prior to a late re-advance.

Headward erosion in the main valley has reached an elevation of about $45^{\circ} \mathrm{m}$ where the river enters its gorge. Below this point three streams draining cirque glaciers have also cut considerable gorges. The gorge on the east side, joining the river at an elevation of $225 \mathrm{~m}$, is particularly striking; very narrow and sinuous in its lower course with nearly vertical walls up to $155 \mathrm{~m}$ high, it is cut in the highly folded Cape Rawson beds. At the bottom of the gorge there is semi-permanent ice from wind-blown snow fillings, in part covered by rock debris, through which the stream has carved a tunnel. Farther up-stream in the main valley, there is evidence of a glacial lake or lakes formerly covering a much larger area of the valley than now, for the river bank exposes 1.5 to $2 \mathrm{~m}$ of fine dark sand, evidently deposited in the still waters of a lake that was possibly dammed by an extension of the large piedmont glacier at the north-east side. At the present time, Yelverton Lake has a permanent ice cover except at the margins in summer. Christie (1963) concluded, from ancient musk-ox bones covered in moss and from large boulders on its surface, that the ice is, at least occasionally, in contact with the bottom either through freezing or through drainage of the lake. He presumed that the surface material had been captured at the bottom of the ice and brought to the surface by differential melting.

In the western arm of the valley, headward erosion and incision right up to the glacier front suggest a longer ice-free period than for the main valley. Here, $4 \mathrm{~km}$ above the main fork, at an elevation of $200 \mathrm{~m}$ above sea-level, a $12 \mathrm{~m}$ section in a terrace above the river shows glacial outwash boulders grading up into shingle, sand and silt layers with some cobbles (Fig. 6). The deposits rest on vertically bedded maroon and olive shales of the Cape Rawson 
group, which have been planed off probably by glacial erosion, and represent a period of heavy outwash from receding glaciers, followed by a period of intense down-cutting after lowering of base level through isostatic adjustment. Terraces at various levels up to $15 \mathrm{~m}$ above the river farther down this arm of the valley are the result of similar processes.

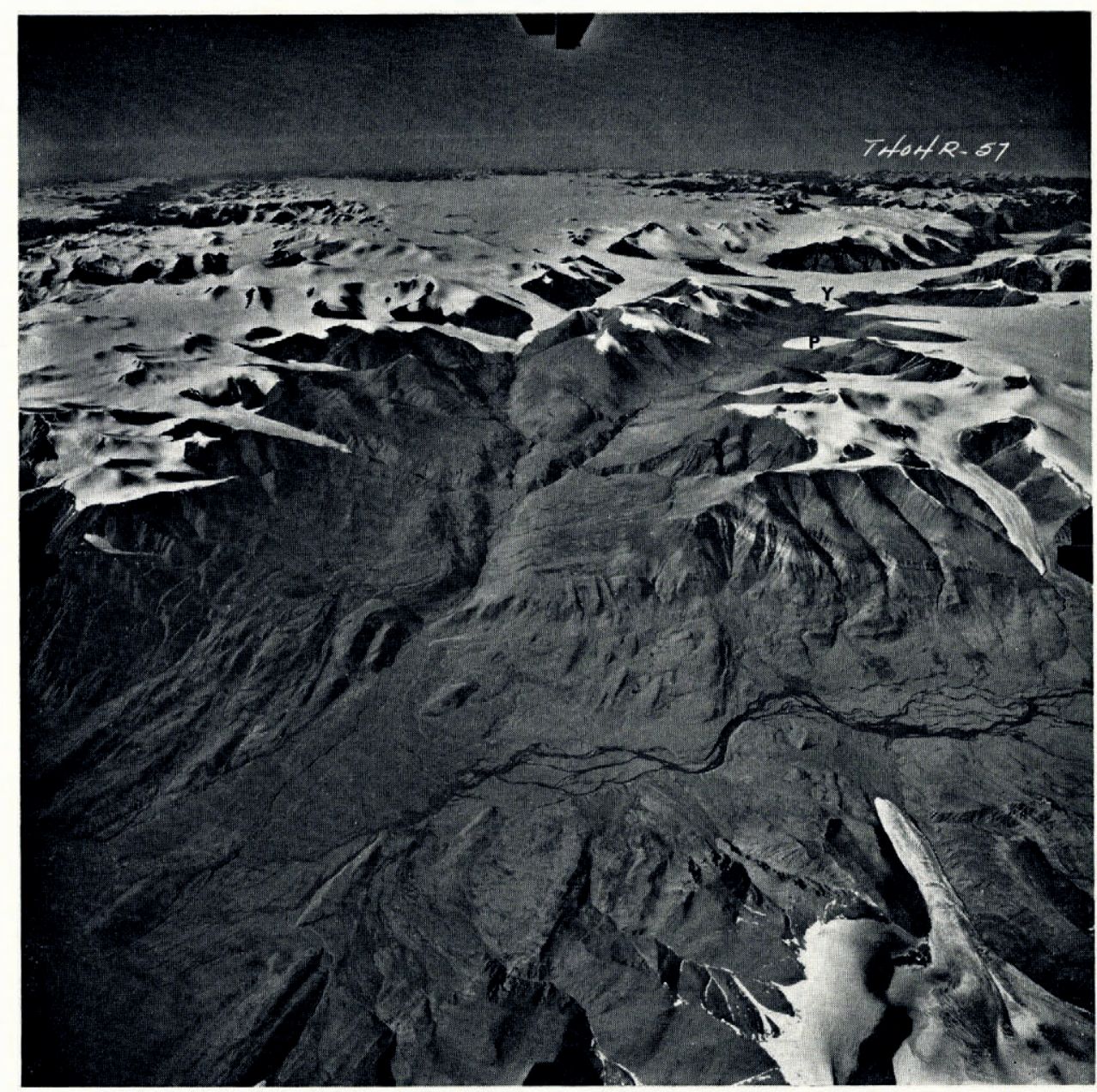

Fig. 5. North-west valley from the south-sast, showing Yelverton Lake $(\boldsymbol{Y})$ and piedmont glacier $(P)$. Oblique air photograph $T_{404 R-57}$ from 6 o95 m, 16 July 1950. (Courtesy of National Photographic Library, Department of Energy, Mines and Resources, Canada.)

There is a striking alignment of the north-west valley with the glacial trough on the southeast side of the Redrock valley and trending north-west to south-east at an elevation of $35^{\circ} \mathrm{m}$, via the Omega Lakes and Redrock Glacier, towards the main fork on the Macdonald River (Figs. 5 and IO). It is difficult to postulate any glacial movement that would account for this alignment.

Air Force valley

The Air Force valley (Fig. 7) is broadly U-shaped but flat-bottomed where the river makes a meandering and braided passage through extensive sandur. Terraces of believed marine origin, up to an elevation of $60 \mathrm{~m}$ above sea-level, occur at least as far as $10 \mathrm{~km}$ up-valley from 
cide water on Tanquary Fiord. Between sea-level and the toe of Air Force Glacier there is a difference of elevation of only I25 $\mathrm{m}$ in a distance of $23 \mathrm{~km}$, and extensive delta deposits occur in the lower part of the valley in the form of terraces or of material re-worked from the terraces over a very wide flood plain, which is shared with the north-west and Rollrock rivers.

As in the north-west valley, intense rock-wasting and solifluction has no doubt obscured or destroyed many glacial features on the valley sides. However, at a distance of only $400 \mathrm{~m}$ from the snout of Air Force Glacier, there are varved layers of sand and silt, with occasional lenses of fine gravel, exposed in the banks of small streams now actively eroding the deposits. The radiocarbon age of $93^{\circ} \pm 140$ years B.P. (GSC-376; Lowdon and others, I957, p. I94) for a sample of willow twigs and leaves from a depth of $110-130 \mathrm{~cm}$ indicates that for at least 900 years the glacier has not been in advance of its present position, although it is now slowly advancing, for vegetation occurs right up to the bank of the ice-marginal stream. The deposits were laid down in a shallow glacial lake probably impounded by moraine between the snouts of Air Force and Fiala Glaciers. It is significant that Fiala Glacier has recently withdrawn from a $12 \mathrm{~m}$ high moraine, composed mainly of large boulders and now being actively eroded at its base by the Air Force River; it might well have extended farther across the valley, although traces of such an advance would have been destroyed by the river. At a much higher elevation ( 1 I $00 \mathrm{~m}$ ), near the margin of Gilman Glacier north of Lake Hazen (Fig. 7), the

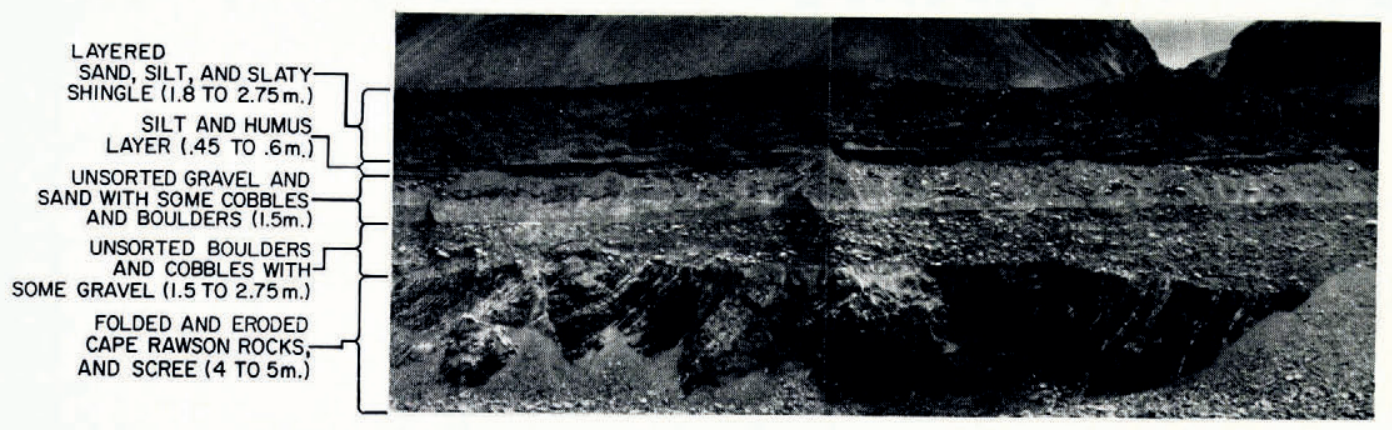

Fig. 6. Section in fluvio-glacial outwash, north-west valley, 4 August 1964 .

present author found plant remains of similar age $(965 \pm 75$ years B.P.; Trautman, I 963$)$. The conclusion is that 900 years ago the major glaciers were not more extensive than today; this is in keeping with findings from study of deep ice cores from north Greenland which show that present snow accumulation and temperature in A.D. 934 were essentially the same as today (Langway, I967).

On the south-east side of Air Force Glacier, where it sweeps round from the direction of Ekblaw Lake, the course of old marginal streams can be traced up to an elevation of at least $200 \mathrm{~m}$ above the present glacier surface. This higher stand of the glacier may also be associated with two moraines or kame terraces on the east and west sides of the valley at estimated elevations of $\mathrm{I} 20$ and $250 \mathrm{~m}$, respectively. That on the east side has been cut across by the twin valley glacier, $3 \mathrm{~km}$ from Air Force Glacier, and that on the west side by three valley glaciers. All these glaciers have recently advanced into V-shaped valleys. Surface lowering of the ice is also demonstrated by features on the west side of Air Force Glacier, where on the hillside in the angle formed with Fiala Glacier a series of moraine terraces occurs up to a height of $100 \mathrm{~m}$ above the marginal stream. Very recent surface lowering is shown by a distinct trim line $10 \mathrm{~m}$ above the stream. Along the ice cliff between Air Force Glacier and Ekblaw Lake, marginal retreat is indicated by the raised delta deposits on the glacier side of a small glacial lake. 


\section{Rollrock valley}

This valley is narrower and more sharply entrenched than the two previously considered and it lies between the Ad Astra and Viking Ice Caps (Fig. 8). It runs down from the glacially dammed Ekblaw Lake, lying at an elevation of $400 \mathrm{~m}$ above sea-level, but it does not drain that lake, for there is a height of land at $560 \mathrm{~m}, 5 \mathrm{~km}$ to the south. The valley is likely to have served as a glacial spillway for the discharging valley glaciers of the two ice caps, and it may

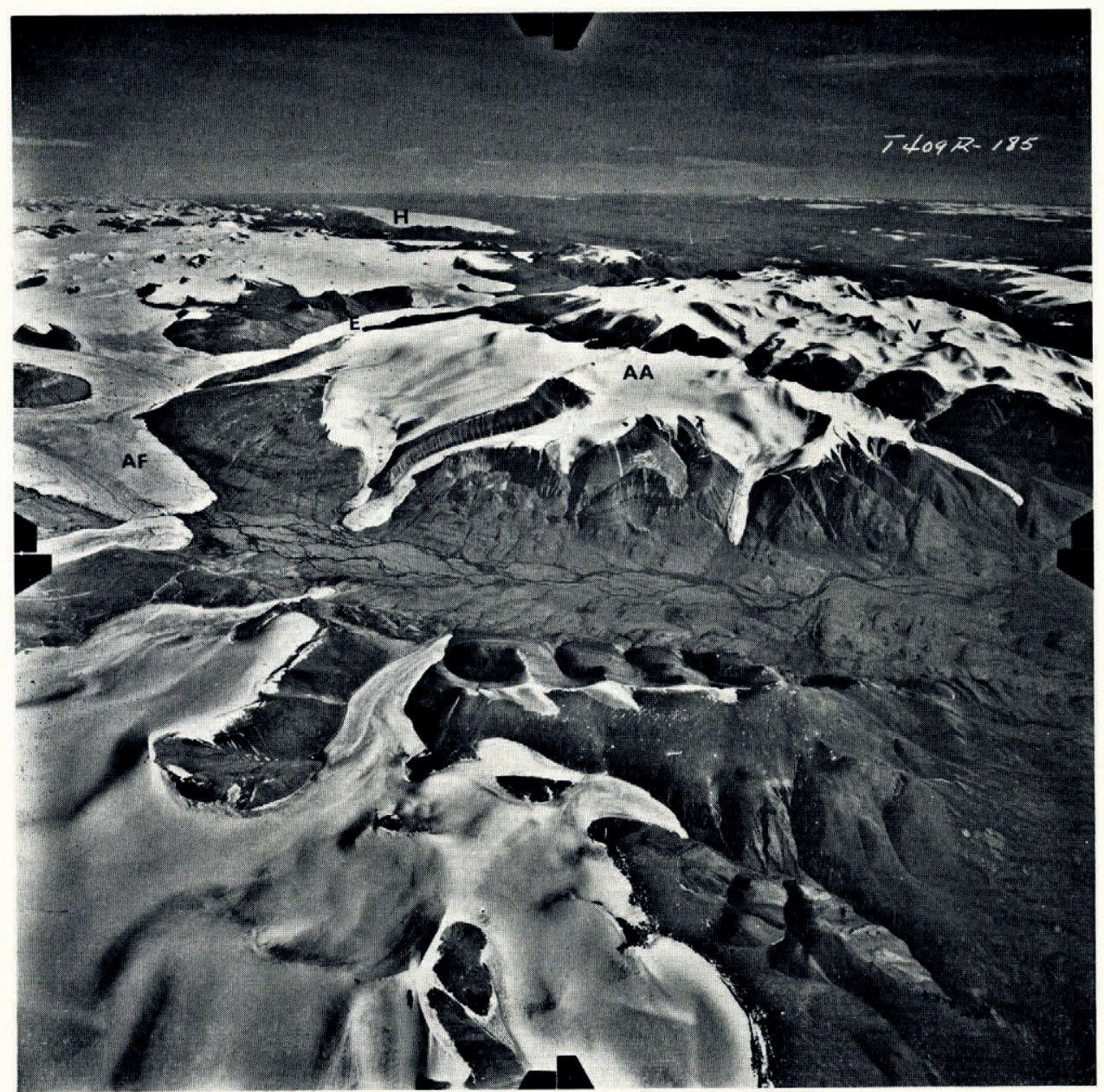

Fig. 7. Air Force valley from the west, showing Air Force Glacier $(A F)$, Ad Astra $(A A)$ and Viking (V) Ice Caps, Ekblaw Lake $(E)$ and Lake Hazen $(H)$. Oblique air photograph T $409 R-185$ from $6095 \mathrm{~m}, 16$ July 1950 . (Courtesy of National Air Photographic Library, Department of Energy, Mines and Resources, Canada.)

also have channelled ice from the extensive south-western part of the central ice cap of Ellesmere Island. In any case, truncated valley spurs and high-level moraines and kame terraces are very well preserved, although the recent history of the valley has been complicated by advances of three glaciers from the Viking Ice Cap across the valley, and by the formation of the glacially dammed Rollrock Lake.

A conical pile of unsorted outwash material, rising 6 to $8 \mathrm{~m}$ above the flood plain, is a curious feature in the middle of the valley, $2 \mathrm{~km}$ from its mouth. It is not a moraine but is the 
result of massive slumping from the north-west side of the valley, originating from a high-level moraine terrace. The slumps have pushed up arcuate banks of outwash material and till, of which the conical pile is a remnant.

The present stands of Rollrock, Steeprock and Tumblerock Glaciers evidently result from late advances since the main withdrawal of ice from the valley. The morphology of the Rollrock and Steeprock piedmonts and their contorted moraine patterns are strongly suggestive

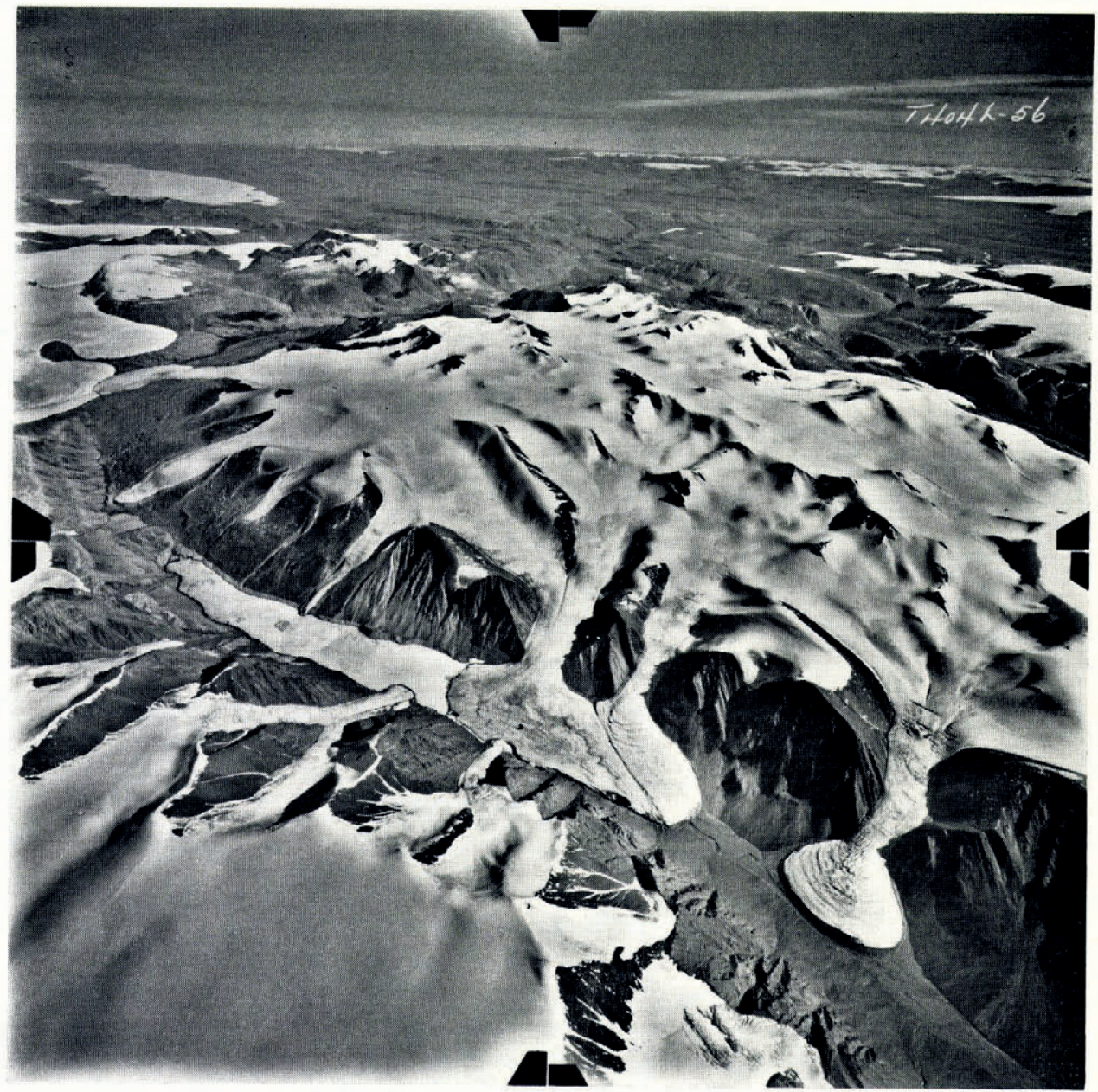

Fig. 8. Rollrock valley and Viking Ice Caps from the west. Oblique air photograph T404L-56 from $6095 \mathrm{~m}, 16$ July 1950 . (Courtesy of National Air Photographic Library, Department of Energy, Mines and Resources, Canada.)

of glacier surges to which the very steep glacially cut walls of the valley may have been conducive. The catastrophic effects of flooding as a result of periodic drainage of Rollrock Lake (see below) suggest that peat deposits down-stream are incompatible with a very long period of glacial lake regime. It is likely, therefore, that glacier advances in this valley long post-date the peat which has a radiocarbon age of $6480 \pm 200$ years B.P. (SI-468; Hattersley-Smith and Long, i 967 ). The peat was exposed in a $6 \mathrm{~m}$ section of the river bank, the top of which was $78 \mathrm{~m}$ above sea-level (Fig. 9) ; $2.5 \mathrm{~m}$ of peat and silt overlie $3.5 \mathrm{~m}$ of cross-bedded sand, gravel 
and shingle with a few boulders, representing a fairly long period of glacial-outwash deposition. The high-level moraines at the sides of the valley date from the last major occupation of the valley by glaciers, more than 7 ooo years ago.

\section{Macdonald valley}

Macdonald valley in its two main branches drains part of the mountainous area between Tanquary Fiord and Lake Hazen, and also a very extensive plateau area to the east (Fig. Io). The drainage comes mainly from snow run-off and to a lesser extent from glaciers and ice caps. Massive glacierization of the valley is indicated by the high-level moraine terrace on the north side, which is 50 to $100 \mathrm{~m}$ wide. It starts at an elevation of $170 \mathrm{~m}$ above sea-level ( $135 \mathrm{~m}$ above the river), near a small kettle lake, and rises through $90 \mathrm{~m}$ in a distance of $3 \mathrm{~km}$ upvalley beneath a $250 \mathrm{~m}$ cliff in Permian and Triassic sandstone, intruded by four basalt sills with an aggregate thickness of about $75 \mathrm{~m}$. On the river side, the moraine is piled 3 to $9 \mathrm{~m}$ higher than on the other side, so that there is a narrow ridge of material at angle of rest above the river, marking a former ice-contact face. There is also a lower moraine terrace, $70 \mathrm{~m}$ wide, with till and large angular blocks at an elevation of $100 \mathrm{~m}$ above sea-level. Both

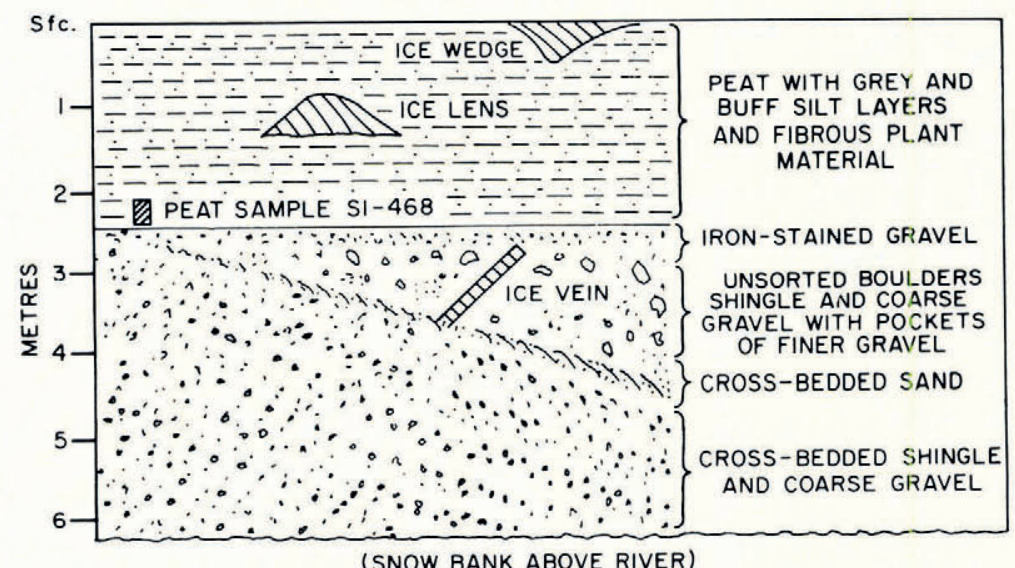

Fig. 9. Section in fluvio-glacial outwash and peat in bank above Rollrock River, 4 May 1966.

moraines slope down towards the end of the second delta terrace at the mouth of the Macdonald River. On the south side of the valley, moraine terraces are best preserved at heights of 89 and $137 \mathrm{~m}$ above sea-level near the kettle lake, $3 \mathrm{~km}$ south-east of Tanquary Camp; the higher terrace is cut by old marginal drainage channels running north-east to south-west. The terraces are rimmed by gravel and shingle ridges on the valley side, indicating ice-contact faces. Irregular terracing occurs below the $89 \mathrm{~m}$ level down to the level of the kettle lake at $62 \mathrm{~m}$. The best-developed ice-marginal channel occurs at an elevation of about $400 \mathrm{~m}$ above the south side of the valley; it has been bisected by the ravine $2 \mathrm{~km}$ south-west of Tanquary Camp and no longer carries a stream.

On the south side of the valley, near the main fork $13 \mathrm{~km}$ from the sea, peat was collected from an exposure in the river bank at an elevation of $128 \mathrm{~m}$ above sea-level. The peat was overlain by $4.3 \mathrm{~m}$ of layered silt, sand, gravel and some shingle, with a few thin peaty layers. The radiocarbon age of the peat was $4060 \pm 130$ years B.P. (GSC-374; Lowdon and others, 1967, p. 194), thus dating from the end of the Climatic Optimum. Conditions for peat formation obtain in northern Ellesmere Island today (Radforth, I965), and conditions were probably more favourable 4 ooo years ago. Peat deposits of similar radiocarbon age, 4 190 \pm 
I 30 years B.P. (GSC-I05), from near the head of Oobloyah Bay to the north of Greely Fiord, have been cited as evidence that the nearby piedmont glacier is now at least as extensive as at any time in the last 4000 years (Dyck and Fyles, 1963, p. 54). In the present case, it is clear that from the mid-part of the Macdonald valley glaciers had receded by at least 4 ooo years ago. Peat formation in the valley-side areas, well-watered by melting snow and side streams, was followed by deposition in river backwaters, and then by down-cutting as the river adjusted

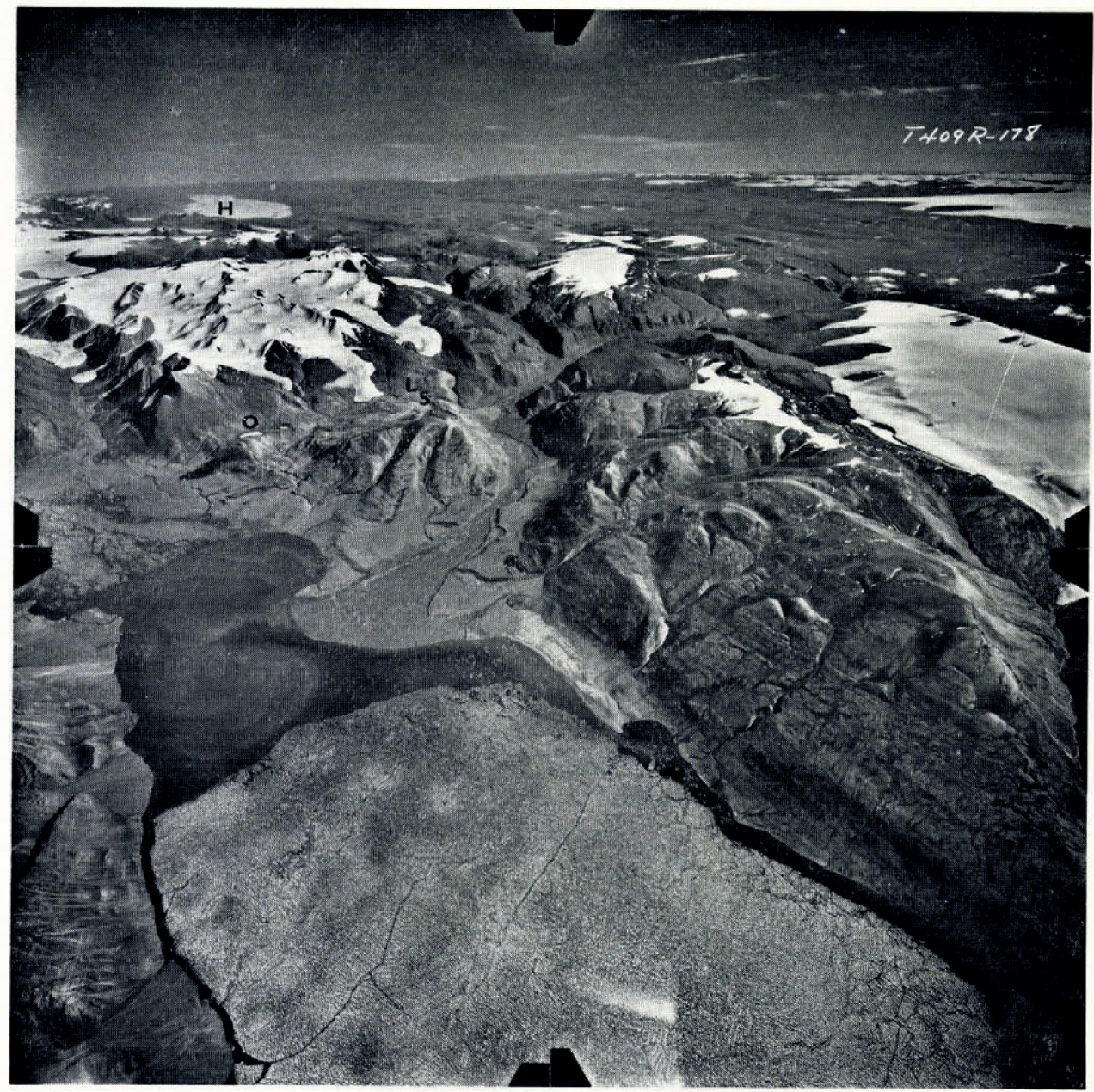

Fig. 1o. Macdonald River from the west, showing Lake Hazen $(H)$, Omega Lakes $(O)$, survey station $(S)$ and lake deposits $(L)$. Oblique air photograph $T_{409 R-178}$ from $6095 \mathrm{~m}, 16$ July 1950. (Courtesy of National Air Photographic Library, Department of Energy, Mines and Reso irces, Canada.)

itself to the very rapid uplift of $3.5 \mathrm{~m} / \mathrm{I}$ oo years that took place between 6500 and 5 ooo years ago (Hattersley-Smith and Long, 1967). The well-developed terraces at three levels at the mouth of the river were the result of alternate build-up and dissection during the general uplift of the last $65^{\text {oo }}$ plus years; build-up or dissection was determined by the supply of material from the waning ice caps of the period. There was corresponding activity where these terraces pass up-river. 
On the plateau at the head of the south-eastern arm of the Macdonald River there appears to be glacial drift of two different ages - an older drift with erratics such as red quartzite, conglomerate and basalt, belonging to a period of vigorous glaciation with ice movement probably from the north-east, and a more recent drift which shows up as irregular mounds that are light-coloured in the air photographs. The latter appears to overlie the older drift, which is more weathered and lichen-covered. The older drift forms the terrain in all valleys, while the more recent drift mantles the sides of the valleys. It is suggested that the newer drift dates from a later "Meighen-type" of ice cap (Arnold, I965), in contrast to a much more severe and widespread earlier glaciation. A large log of driftwood, found at an elevation of $570 \mathrm{~m}$ at the head of the Macdonald valley, may be associated with such an earlier glaciation. The box-type form of the upper part of the Macdonald valley is compatible with a recent protective ice cap of the "Meighen-type" over the upper slopes of the hills and the plateau to the east, and with a long period of fluvial erosion concentrated in short summers. Because of permafrost conditions, a very high proportion of available water forms run-off. Snowfall varies from 100 to $200 \mathrm{~kg} \mathrm{~m}^{-2}$ year-1 according to altitude, but, in summers of strongly negative glacier mass balance, run-off may greatly exceed the snow accumulation of catchment areas. In all four valleys at the head of Tanquary Fiord, but especially in the Macdonald valley, the rivers have played a major role in recent morphological evolution.

\section{Indicators of Ice Movement}

It has frequently been stated that the usual signs of glacial erosion, such as roches moutonnées, glacial striae and the like, are lacking in the northern Queen Elizabeth Islands (e.g. Souther in Fortier and others, 1963 ; Rudberg, 1963 ), and this has been attributed to weathering and frost action. However, indicators of glacial movement are by no means lacking in the Tanquary Fiord area, wherever suitably resistant bedrock is exposed or wherever sufficiently large obstacles have impeded glacial movement.

\section{Roches moutonnées}

The most striking roches moutonnées are the two large knolls near the mouth of the Air Force valley. These unmistakably indicate glacial movement down-valley in an almost due south ( $176^{\circ}$ true) direction, as shown by glacial striae. The larger of the two knolls, rising to a height of $53 \mathrm{~m}$ above sea-level, is situated about $2 \mathrm{~km}$ south-west of Per Ardua Glacier. Bedrock phyllites of the Cape Rawson series are well exposed on the south and south-east sides of the knoll, where there is a clear marine-cut notch at an elevation of about $40 \mathrm{~m}$ above sea-level. On the other sides, marine silts are held up against the bedrock, and good sections in the silts are exposed. The top of the knoll is lightly covered with marine silts, with some fluvio-glacial shingle and boulders, which also occur around the sides. The other roche moutonnée is $3 \mathrm{~km}$ upvalley from the latter and reaches an elevation of $98 \mathrm{~m}$ at its highest point; it is also formed in Cape Rawson bedrock which is here greywacke. It displays broad very well-developed glacial grooving, giving the direction of ice movement.

\section{Glacial striae}

Apart from the examples already cited, glacial striae were observed in several other localities in Triassic sandstone, which favours good preservation. Thus on the east side of Air Force Glacier, at an elevation of $290 \mathrm{~m}$ above sea-level or about $165 \mathrm{~m}$ above the toe of the glacier, a glacial pavement is very well preserved on a moraine terrace, about $100 \mathrm{~m}$ wide and sloping at $10^{\circ}$ towards the valley. Striations and chattermarks give the direction of movement along the line of the valley. The pavement is partly covered by unsorted deposits ranging from silts to large water-worn boulders (Fig. I I).

On the south-east side of the head of Tanquary Fiord there are excellent examples of glacial pavements and glacial striae, also preserved in Triassic sandstone. Near the ravine 
$2 \mathrm{~km}$ south-west of the camp, at a minimum elevation of $170 \mathrm{~m}$, glacial striae occur in the horizontal plane, trending approximately $230^{\circ}$ true. Here, an erratic boulder of basalt was seen resting on a pavement of shallow polished swales of about $1 \mathrm{~m}$ amplitude. Glacial pavements are also well-developed in association with the moraine terraces on the hillside above the kettle lake at a height of $137 \mathrm{~m}$, and glacial striae are well seen in sandstone $3 \mathrm{~km}$ to the southwest of the camp and $7 \mathrm{~m}$ above sea-level. All these features indicate glacier movement downfiord.

On the north side of the Macdonald River, glacial striae at higher levels are found. Thus, on the ridge south-west of the survey station (Figs. 2 and Io), glacial striae and chattermarks indicating due west ice movement occur at an elevation of $570 \mathrm{~m}$, and a glacial pavement with erratics occurs at $510 \mathrm{~m}$. At an elevation of $775 \mathrm{~m}$, there were fluvio-glacial erratics of gravel,

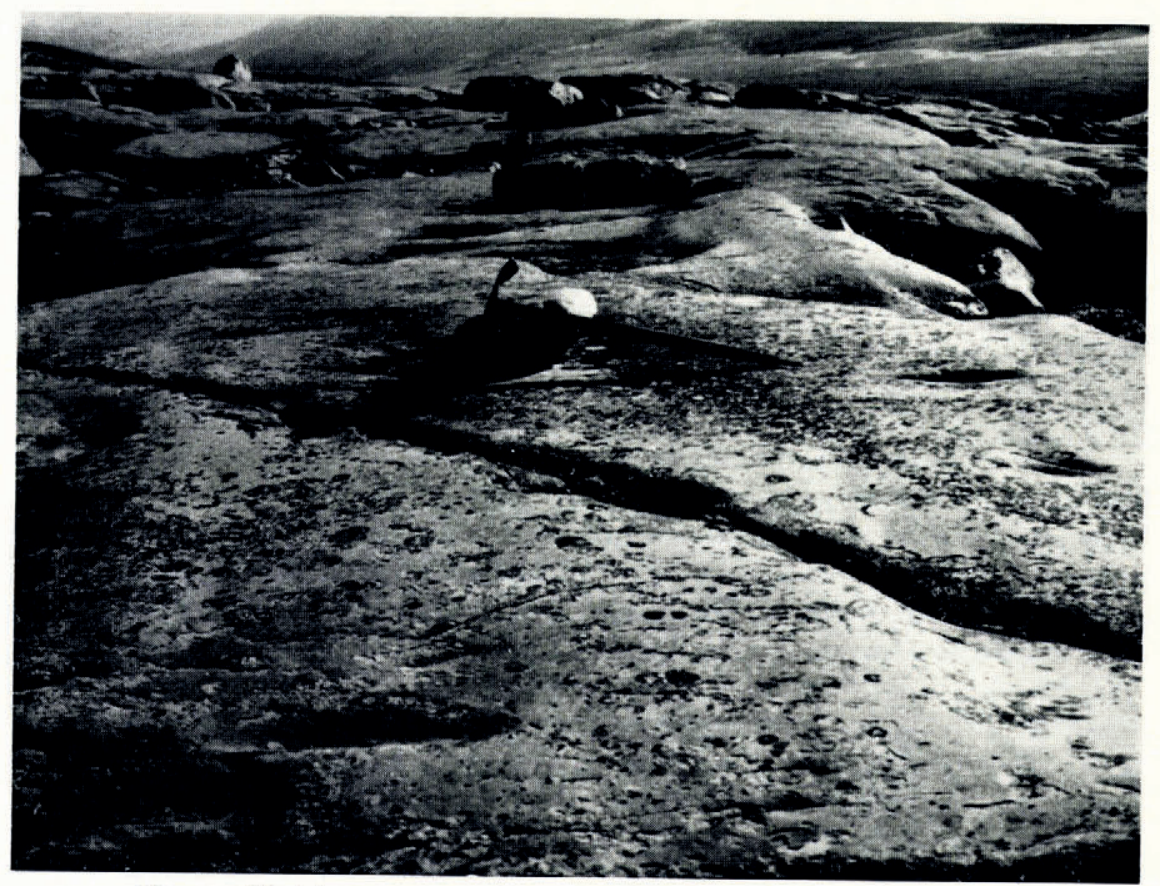

Fig. 11. Glacial pavement near the tongue of Air Force Glacier, 4 August 1965.

shingle and water-worn cobbles, with large blocks of grey and olive shale, chloritic quartz and quartzite of the Cape Rawson group, and basalt resting on Triassic sandstone, dipping at an angle of about $20^{\circ}$. On the north side of the hill, the highest erratics were found at an elevation of $840 \mathrm{~m}$ near the top of the hill. These observations indicate considerable inundation by glacial ice. Similarly, on the south side of the Macdonald valley, high on the ridge above Tanquary Camp, there are large, rounded erratic boulders of basalt and limestone at an elevation of $505 \mathrm{~m}$, and a striated glacial pavement at $425 \mathrm{~m}$.

\section{Glacial Lakes}

In flying over north-western Ellesmere Island, the observer is struck by the number of glacial lakes, most of which are well shown on the I : 250000 maps. In general, these lakes are of two types: (a) those formed in a main valley by the advance of a glacier or glaciers 
across the valley, and (b) those formed strictly marginal to a glacier where it blocks off an ice-free or partly ice-free tributary valley, or where it has receded from the valley wall. Although there have been a number of recent references to glacial lakes in the Arctic (e.g. Weidick, I 963 ; Helk, I966; Maag, unpublished), perhaps not enough attention has been given to their significance or otherwise as climatic indicators and to their importance in the geomorphological cycle. Helk (1966) in particular referred to the lack of knowledge of these phenomena, and drew attention to the chance discovery during the course of aerial mapping of a very large glacial lake in south-west Greenland, and discussed the problem of its periodic drainage.

It is characteristic of glacial lakes to show sudden and rapid changes in level and extent, accordirg to fluctuations of the confining glaciers. In fact, in north-western Ellesmere Island all the lakes that have been observed on the ground or from the air show strand lines well above present levels. Thus, two lakes in the main valley 20 to $40 \mathrm{~km}$ from the head of Emma Fiord (Fig. I), each about $10 \mathrm{~km}^{2}$ in area, showed old strand lines from 15 to $50 \mathrm{~m}$ (estimated) above the water-level of mid-July ig63. And a small marginal lake on the west side of Chapman Glacier showed an old strand line about $10 \mathrm{~m}$ above water-level on the same date. To the north of Lake Hazen (Fig. 7), on the east side of Henrietta Nesmith Glacier, $6 \mathrm{~km}$ from the terminus, Smith (196I) described a marginal lake with strand lines up to $37 \mathrm{~m}$ above the lake level of July 1958, or approximately level with the then surface of the glacier. His observations led him to deduce very recent thinning of the glacier.

In the Tanquary Fiord area we are particularly concerned with two very large lakes, Ekblaw Lake and Lake Tuborg, and with the smaller Rollrock Lake, all of type (a) above.

\section{Ekblaw Lake}

Ekblaw Lake, situated at an elevation of $402 \mathrm{~m}$ above sea-level at the head of the Lewis River, has an area of 25 to $30 \mathrm{~km}^{2}$; it is held back by the lobes of Scylla and Charybdis Glaciers coming from the south-west and north-east sides of the valley, respectively, so that their snouts are contiguous (Figs. 7 and 8). The Lewis River has carved an ice gorge where the two lobes join. The depth of this gorge is not known beyond the fact that it is at least $20 \mathrm{~m}$; nor is it known whether it is cut through to the glacier soles.

The bathymetry of Ekblaw Lake is also unknown, except for a single sounding in $68 \mathrm{~m}$ near the middle of the lake about halfway along its length (personal communication from A. Long, 1967). The mouths of three streams, one on the north side and two on the south side, are noticeably drowned where they broaden out over what are now submerged outwash fans. Maximum drowning occurs on the north side and amounts laterally to $300-400 \mathrm{~m}$, which on geomorphological grounds is consistent with a lake depth not exceeding roo $\mathrm{m}$. The two streams on the south side have incised deeply into soft sediments of Jurassic age. The lake has, however, been much deeper, as shown by a high strand line at an elevation of about $43 \mathrm{~m}$ above present lake level, according to rough levelling. This strand line is best seen at the west end of the lake, where there is a pronounced lichen trimline at the surface of the Triassic sandstone, very clearly seen both on the ground and in the air photographs; the sandstone is a lighter shade of brown below the trimline. Elsewhere the trimline is shown by the sparsity of vegetation below it; there are no clearly defined raised-beach lines at lower levels. The elevation of the trimline is about I $5 \mathrm{~m}$ below the height of land at the head of Rollrock valley, and there is no evidence that the lake ever drained down this valley. Near the west end of the lake there was a recent ice-pushed ridge at an elevation of about $15 \mathrm{~m}$ above the lake level of 5 August 1965 , and indications of several recent lake stands below the $15 \mathrm{~m}$ level. The lake level, as might be expected, rises rapidly in mid-summer with the inflow of melt water from the glaciers and falls gradually in late summer and autumn. Thus, near the edge of the lake on the above date, Arctic poppies were in flower while submerged in $15 \mathrm{~cm}$ of water, and grass was also visible on the bottom of the lake in water I $\mathrm{m}$ or more deep. Evidently the 
lake is well up to or perhaps very slightly above its mean level of recent decades. The air photographs give no indication of Aufeis in the valley below Scylla and Charybdis Glaciers, and such was not observed on a foot reconnaissance, so there appears to have been no very recent history of catastrophic drainage involving flow of water during the winter.

There is no information on when Scylla and Charybdis Glaciers-either independently or together-advanced across the valley, but on general grounds it is likely to have been an event of the last few thousand years or even few centuries. (A good example of possible incipient damming of this kind can be seen in a valley near the head of Emma Fiord where two glacier tongues are separated by only a few hundred metres of bare ground.) Except at the medial gorge, the ice cliffs rise up to $40 \mathrm{~m}$ above lake level. A good deal of subglacial and englacial debris may have been involved in the original damming process, but it is necessary to postulate a glacier surface about $20 \mathrm{~m}$ higher in the medial section for the lake level of the $43 \mathrm{~m}$ strand line to have been possible. Evidently the lake stayed at this level long enough (it may have been only a few years) to destroy the submerged lichen and plant growth, which has still not recovered. Once a channel could be cut, perhaps partly by supraglacial outlet streams and partly by melting and calving at the ice front, the lake would drain rapidly. The recession represented by the recent exposure of a $100 \mathrm{~m}$ wide strip of bedrock on the north side of the lake may have been enough to trigger the lowering of lake level. Conversely, only minor advances of the glaciers could again cause the lake level to rise; no major climatic fluctuations need be involved. It may be possible to obtain data on the age of the lake by sampling organic material (including peat and remains of land plants) from the lake bottom for radiocarbon dating.

The former direction of ice movement in the valley now occupied by Ekblaw Lake was west-east along the valley, as shown by glacial striae on the knolls formed by basalt sills near two kettle lakes halfway along the south side of the lake at an elevation of about $500 \mathrm{~m}$.

\section{Rollrock Lake}

Rollrock Lake is about $5.5 \mathrm{~km}$ long and less than I $\mathrm{km}$ wide, and is situated near the head of the Rollrock valley (Fig. 8); the long profile of the valley, based on an altimeter traverse in 1963 , is given in Fig. 12. At the time of this traverse the elevation of the lake above sea-level

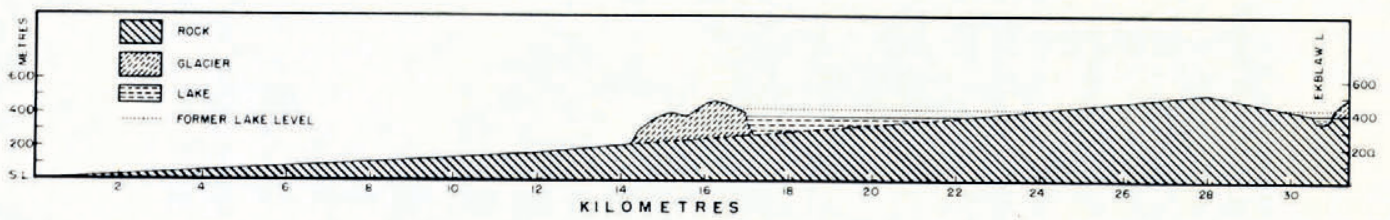

Fig. 12. Longitudinal profile of Rollrock valley, from sea-level at the head of Tanquary Fiord to Ekblaw Lake, based on an altimeter traverse in fuly 1963 .

was about $385 \mathrm{~m}$, and the elevation of the highest part of the Rollrock Glacier piedmont that dams it was $475 \mathrm{~m}$. Extrapolation of the bedrock profile of the valley upwards shows that the glacier has a thickness of not more than $200 \mathrm{~m}$. According to measurements at the ice barrier in 1965 , the depth of water was $87 \mathrm{~m}$ (personal communication from J. E. Keys), and near the middle of the lake in 1967 a single sounding was made in $51 \mathrm{~m}$ (personal communication from A. Long).

The terrain on the two sides of the lake is strikingly dissimilar. On the east side, in the southern section as far north as the small glacier, the shoreline is composed of scree and moraine lying at angle of rest; north of the glacier tongue, bedrock of massive brown Triassic sandstone is exposed, dipping north at an angle of about $32^{\circ}$. The west side follows the faulted contact of Upper Jurassic shale and Lower Cretaceous sandstone with rocks of the Cape Rawson 
group; the shales are exposed on moderate slopes for a few hundred metres above shore. A lichen trimline, representing a recent high strand level of the lake, is strikingly displayed in the air photographs and on the ground, on the east side, but it is less noticeable on the west side. In July $\mathrm{I}_{9} 6_{3}$, this strand line was at an elevation of $52 \mathrm{~m}$ above the level of the lake (Fig. I2), but there have been seasonal oscillations of lake level since then.

At the northern end of the lake, sands and silts occur in the form of delta terraces rising about $20 \mathrm{~m}$ above lake-level. The deposits, which contain small pieces of drift coal from the Triassic sandstone and sticks of drift willow, indicate stands of the lake over a number of years at the various levels. On the west side of the lake, the principal stream draining a glacier from the Ad Astra Ice Cap has formed about eight delta terraces up to an estimated $30 \mathrm{~m}$ above lake-level. Evidently in the past, as at present, there have been frequent changes of lake level. One such change in lake level undoubtedly occurred in $1965^{-66}$. It is believed that

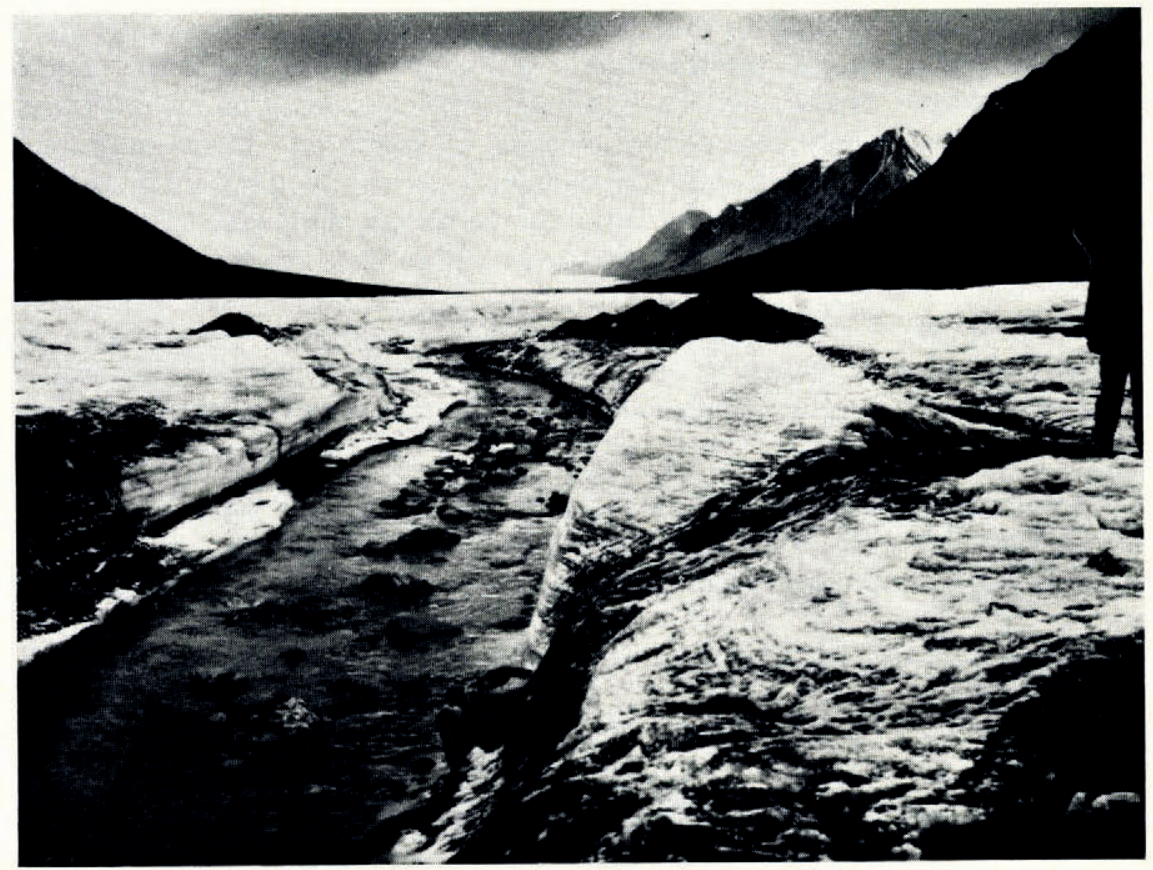

Fig. I3. Aufeis in Rollrock valley, 16 June 1967 .

the lake began a heavy discharge in late July 1965 , when it was noted that the flood plain at the mouth of the Rollrock River showed unusually large areas of water and when extensive erosion of peat bogs on the east side of the flood plain is known to have occurred. Drainage of the lake evidently continued slowly long into the freeze-up period in late autumn and early winter, because in the 1966 summer U. Embacher (personal communication) reported a massive development of Aufeis below the Rollrock Glacier snout (Fig. 8). The Aufeis reached a thickness of $6 \mathrm{~m}$ in places and large quantities of gravel had been deposited on its surface (Fig. 13); no Aufeis was seen in this valley prior to 1966 . Between the spring of 1965 and the summer of 1966 the level of Rollrock Lake had fallen by $25 \mathrm{~m}$.

It seems likely that the drainage of Rollrock Lake and the resulting ice flood is controlled by the activity of the marginal stream on the west side and by calving along the ice front of Rollrock Glacier. The critical point is probably where the glacier tongue from the west side 
impinges on this ice front. It is possible that the larger glacier riding up over the smaller one is the immediate trigger for a release of water. Once started, the surge of water sweeps away debris and rapidly enlarges drainage channels. At any rate there is no evidence of subglacial drainage, or of the stream tunnelling its way out owing to creep of the ice under hydrostatic pressure at the barrier in the manner put forward by Glen (1954). Indeed the depth of water, $87 \mathrm{~m}$ (admittedly from one sounding only), at the ice barrier would not, according to Glen, be great enough for this to occur, although it may perhaps occur in certain glacial lakes in south Greenland (Weidick, I963). Nor is it possible that the glacier, $200 \mathrm{~m}$ thick, is floated off, except perhaps very locally along marginal crevasses. The erosion and movement of material down-stream and the rapid changes caused in the drainage channels are processes of considerable geomorphological importance.

Rises in the level of the lake could be caused from time to time by Rollrock Glacier and the small glacier at the south-west corner of the lake advancing. Both these glaciers send a limited number of icebergs into the lake.

\section{Lake Tuborg}

Lake Tuborg is situated at the head of Antoinette Bay, the central arm of Greely Fiord (Fig. 14). The lake, which is the natural extension of the fiord, is held back by a large tidewater glacier, flowing northward from the Mer de Glace Agassiz to the south-east; it occupies a wide deep valley enclosed on either side by mountains in the Cape Rawson group, which rise very steeply from the lake to a height of more than $700 \mathrm{~m}$. The lake is $20 \mathrm{~km}$ long and in its western two-thirds averages $3 \mathrm{~km}$ in width, narrowing to about $\mathrm{I} \mathrm{km}$ in its eastern one-third. It receives the drainage from an area of about $400 \mathrm{~km}^{2}$ of the plateau to the north in deeply incised V-shaped valleys, the drainage from the large glacier at its eastern end, and the drainage from an area of about $300 \mathrm{~km}^{2}$ on the south side, where the streams are glacier-fed from the Mer de Glace Agassiz. The glacier at the eastern end occasionally calves small icebergs into the lake.

The lake is approximately $9 \mathrm{~m}$ above sea-level, and this precludes any present connexion with fiord water beneath the glacier, whose tongue appears for the most part to be grounded below sea-level. The level of the lake is not an indication of land uplift, for it is strictly controlled by the glacier and associated moraine dam, which permits only a limited drainage down the marginal stream on the north side of the ice front. On the other hand, the two major rivers flowing into the lake, one on the north and one on the south side, have formed the terraced deltas characteristic of the mouths of all major rivers in north-western Ellesmere Island. There are four main terrace levels above the lake, up to an elevation of $87 \mathrm{~m}$ above sea-level, which is also the level of the highest delta terrace of the Macdonald River at the head of Tanquary Fiord (Hattersley-Smith and Long, 1967); the lowest terrace is at an elevation of $21 \mathrm{~m}$. Marine shells (Hiatella arctica) were found at an elevation of about $3^{8} \mathrm{~m}$ above sea-level near the delta on the north side of the lake. At the eastern end of the lake on the north side, marine silts form a barren area of mud flats with scattered angular rocks and pebbles, extending for about $2 \mathrm{~km}$ along the shore and rising to an elevation of $33 \mathrm{~m}$ above sea-level ( $24 \mathrm{~m}$ above lake-level). The rocks and pebbles are clearly ice-rafted either by sea ice or by icebergs (Fig. I5). A similar area occurs just south of Tanquary Camp and rises to a similar level. It is assumed that these deposits represent a raised marine rather than lake beach, and it is also concluded that the delta terraces relate to the time before the lake was cut off from the sea.

The limnology of the lake is of particular interest, since below a depth of about $50 \mathrm{~m}$ the fresh water rests on a layer of sea-water of salinity $25 \%$ (Hattersley-Smith and Serson, 1964); the greatest depth measured near the centre of the lake was $130 \mathrm{~m}$ (personal communication from A. Long, 1967). It is assumed that the lake resulted entirely from damming by the glacier at the west end, which in the process entrapped the sea-water and with it the relict 
plankton fauna described by Bowman and Long (1968). From the radiocarbon age of bicarbonate in the sea-water, the advance of the glacier occurred about 3 ooo years ago (Long, 1967) at a time when the sea-level was about $7 \mathrm{~m}$ higher, according to a post-glacial uplift curve for Tanquary Fiord (Hattersley-Smith and Long, 1967). Since the lake is now about $9 \mathrm{~m}$ above sea-level, the water is very close to its original level before it was cut off from the fiord. This agrees with the assumption above that the beach deposits and delta terraces were formed under marine conditions.

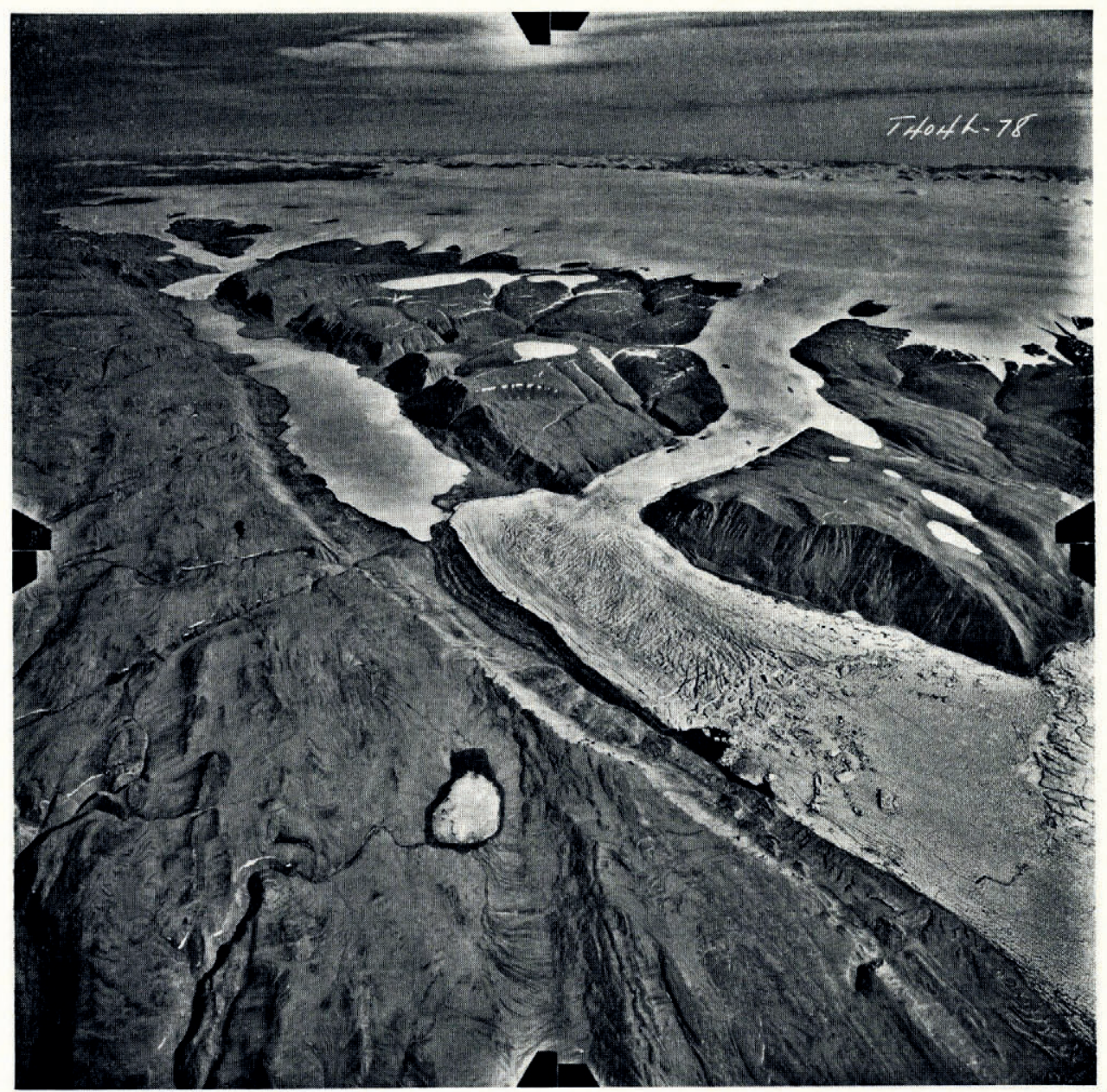

Fig. 14. Lake Tuborg from the west, showing the unnamed glacier at the head of Antoinette Bay that retains the lake. Oblique air photograph $T_{404} L-78$ from 6095 m, 16 July 1950. (Courtesy of National Air Photographic Library, Department of Energy, Mines and Resources, Canada.)

Observations show that the top of the saline layer in the lake lies about $40 \mathrm{~m}$ below present sea-level. Two possible explanations for the depth of the saline layer come to mind: (I) the fresh-water layer has undergone a slow process of mixing with the sea-water, or (2) there has been some mechanism by which the sea-water has been able to escape beneath the ice barrier. If the glacier floated off from time to time after the lake had filled up above sea-level, then the heavier sea-water could flow out beneath the glacier, until hydrostatic pressure on either side 
of the barrier was equalized. If the glacier then went aground again, the lake would start refilling with fresh water; in this way fresh water would be accumulated at the expense of seawater to the level controlled by the marginal outlet. To float the glacier off, it would be necessary, however, to postulate thinning of the tongue either through a prolonged period of heavy ablation or through surging and the thinning that accompanies this process. There is some evidence that the glacier is at present undergoing a minor surge. Certainly, since the author first visited Lake Tuborg in 1963 , there has been a marked increase in the activity of the glacier, which has forced its way nearer to the north wall of the valley and has in part floated off at the seaward margin. This activity has been responsible for considerable disruption and buckling of the sea ice near the ice front. It has also caused gushers of sea-water to be thrust up several metres above sea-level in the narrow pass between the glacier and the valley wall,

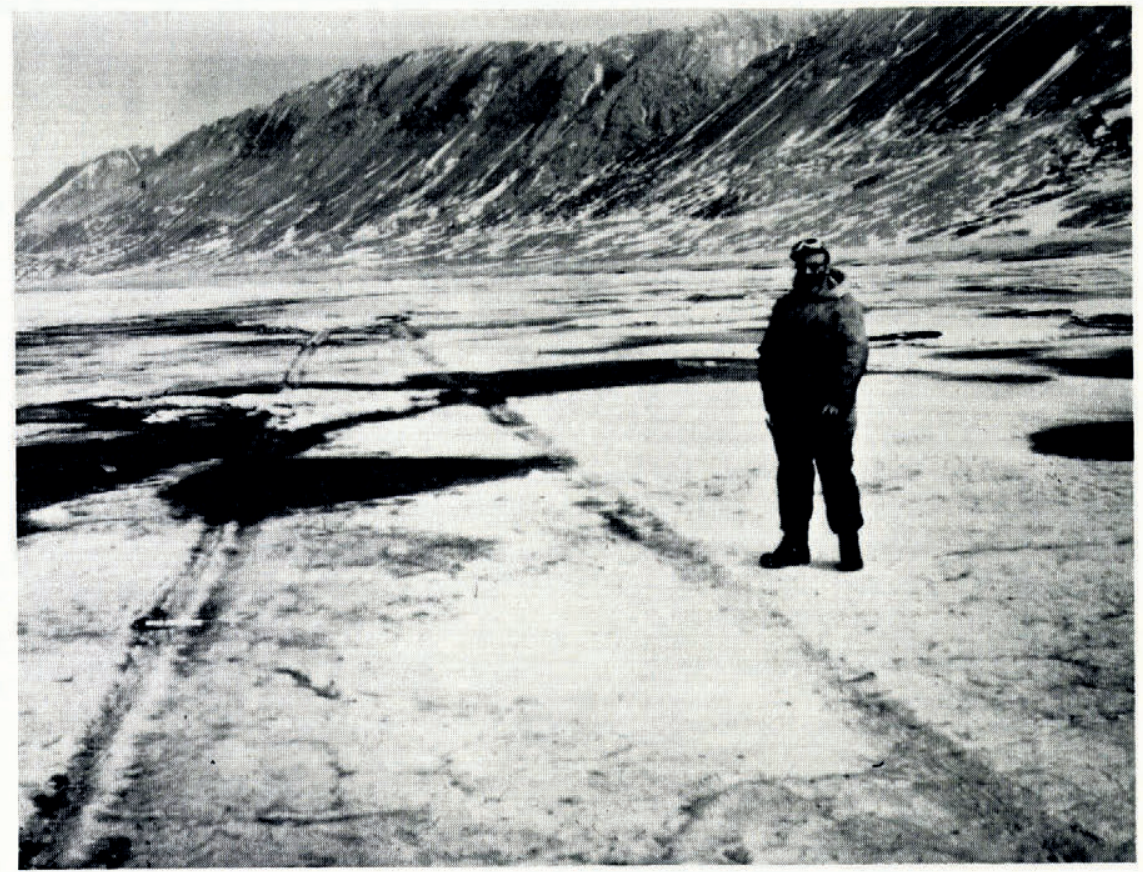

Fig. 15. Skid-tracks made by an iceberg on the seasonally flooded margin of Lake Tuborg, I June 1963.

where the glacier is over-riding dead ice covered by very fresh-looking moraine of a recent recession. Such movement of the glacier might in itself open up a channel through which water from the lake could drain, assisted possibly by flotation of part of the ice mass.

While there is no ready explanation for the level of the saline layer in the lake, it is clear that the lake at the present time is close to its highest level, for no lake storm beaches or strand lines occur at an elevation of more than $2.5 \mathrm{~m}$ above the lake.

\section{Glacial Lake Deposits}

Two series of glacial lake deposits were examined in the Tanquary Fiord area-one in an upland valley between Redrock Glacier and the Macdonald River, and the other in a river valley on the north shore of Tanquary Fiord opposite Cape Gleason. A third series near Lake Tuborg was also examined. They record the onset of waning glacial conditions when glacier ice still occupied at least the upper ends of Tanquary and Greely Fiords. 


\section{Redrock Glacier deposits}

These deposits are situated in the drainage area from the Viking Ice Cap and they occupy a river valley trending south into the Macdonald valley; the river carries the melt water from Redrock and Cleaves Glaciers. At an elevation of $290-315 \mathrm{~m}$ above sea-level, up to $22 \mathrm{~m}$ of varve clays are exposed over an area of rather less than $\mathrm{i} \mathrm{km} \mathrm{km}^{2}$, where they are being heavily eroded by the river (Fig. Io). The deposits, which are horizontally bedded and reddish in colour from the red Permo-Carboniferous sandstone and conglomerate exposed higher up, mark the site of a glacially dammed lake formed at a time when the Macdonald valley was occupied by a glacier. A few ice-rafted pebbles and boulders rest on the eroded surface of the varve clays and they can also be seen embedded in the section. The lake was drained by a deeply incised hanging valley, which falls through about $300 \mathrm{~m}$ to the Macdonald River. Level terraces on either side of the hanging valley at an elevation of $320 \mathrm{~m}$ show sections in silts overlain by greyish shingle and gravel. Drainage of the lake no doubt took place rapidly with the withdrawal of the ice from the main valley, but the deposits themselves probably represent lake sedimentation over at least many hundred years.

\section{Valley deposits opposite Cape Gleason}

These deposits occur at an approximate elevation of $75 \mathrm{~m}$ above sea-level in the valley of the river which forms the delta on the west side of Tanquary Fiord, $4 \mathrm{~km}$ north-west of Cape Gleason (Fig. I). A section is well-exposed in the west bank of the river for several hundred metres, about $2 \mathrm{~km}$ from the mouth. The section showed about $6 \mathrm{~m}$ of buff-olive varve clays and silts, exhibiting cross-bedding, overlain by $1.5^{-2} \mathrm{~m}$ of boulders, shingle and gravel, with $1.5 \mathrm{~m}$ of silt and sand at the surface. The section, which is being heavily eroded by the river, wedges out down-stream where the valley deposits consist only of boulders, shingle and gravel. The varve sediments were laid down in a glacial lake marginal to a glacier occupying Tanquary Fiord in a period more than 7 ooo years ago, when sea-level was about $60 \mathrm{~m}$ higher than today (Hattersley-Smith and Long, ig67). Subsequent withdrawal of the ice and deposition of coarse glacial outwash, followed by silt and sand, terminated the glacial lake episode. Subsequent rebound of the land, as the glacier and ice caps receded, led to down-cutting of the deposits by the river.

\section{Lake Tuborg deposits}

There is evidence of a late glacial stand preserved on the north shore of the lake, $6 \mathrm{~km}$ from the glacier at the east end. Well-preserved varve clay deposits occur at the site of a former kettle lake, which was held back by a moraine to the south-east, I $\mathrm{km}$ east of the main delta on the north shore (Fig. 14). The base of these varve clays is at an elevation of $43 \mathrm{~m}$ above sea-level ( $34 \mathrm{~m}$ above lake-level), which is well below the marine limit as shown by the delta terraces. The exposure was 8-10 $\mathrm{m}$ in thickness in buff and grey clays, rising about $3 \mathrm{~m}$ above the holding moraine. Clearly, the kettle lake was an ice-marginal feature of the glacier occupying at least the upper part of Lake Tuborg after isostatic adjustment had started or within the last 6500 years (Hattersley-Smith and Long, I967). The varves were seen to average $\mathrm{I}-3 \mathrm{~cm}$ in thickness and to be flat-lying apart from occasional slumping. Some fragments of rock, including a flat, $20 \mathrm{~cm}$ long piece of Cape Rawson phyllite, presumably ice-rafted, were bedded with the varves. The deposits represent a minimum of about 400 years' accumulation.

A glacial advance, possibly contemporary with the varve deposits, is represented by a moraine terrace off the glacier at the east end of the lake. This terrace rises $12 \mathrm{~m}$ above the marginal river, which has exposed a $6 \mathrm{~m}$ section in silts and sands, overlain by $2 \mathrm{~m}$ of till and underlain by planed-off bedrock of the Cape Rawson series. 
Recent Moraines

It has been seen above that one of the major glaciers in the area, Air Force Glacier, is very close to its maximum advance of the last 900 years; the same is probably true of Gilman Glacier (Hattersley-Smith, I96I[b]), Henrietta Nesmith Glacier (Smith, I96I) and other major glaciers in northern Ellesmere Island. On the other hand, all the side glaciers of the Tanquary Fiord area have distinct terminal moraines separated from the ice by up to $300 \mathrm{~m}$ of bare ground.

A piedmont glacier, $530 \mathrm{~m}$ above sea-level, on the north-east side of the north-west valley provides an excellent example of very recent recession (Fig. 5). The glacier ends in a steep, in places vertical, cliff up to I $5 \mathrm{~m}$ high, from which calving occasionally occurs. The glacier is flanked by a moraine that extends for about $100 \mathrm{~m}$ from the frontal part of the piedmont and narrows out at an elevation of 900-I $000 \mathrm{~m}$, where the piedmont debouches from the ice cap to the north-east. The moraine has a very recent appearance and it consists of angular and sub-angular material ranging from pebbles to very large blocks (up to ${ }_{1} 5 \mathrm{~m}^{3}$ in size), most of which have slid down from the ice front. The material is brown sandstone and basalt, and it is devoid of lichens. Lichen-covered, sub-angular and rounded boulders and till form the surface in front of and also underlie the moraine. It was noted that, within the moraine limits, patches of the older drift had the lichen cover less well-developed than outside the moraine, and it was concluded that the material had recently been uncovered by the glacier. Between the ice and the moraine limit some mosses had established themselves, and a few flowering plants (mainly Arctic poppies) were growing sparsely. The ground outside the moraine was normally vegetated. The glacier on the north-east side of Yelverton Lake shows a similar recession of 80 to $100 \mathrm{~m}$, where a deep melt-water gorge from the ice front drains into the lake.

Glaciers in the Rollrock and Air Force valleys also provide excellent examples of recent recession. The moraine around the snout of Tumblerock Glacier rises to a height of $18 \mathrm{~m}$ above the surface of the older drift at its outer edge, which is approximately $140 \mathrm{~m}$ from the ice front. Large debris cones occur near the ice front and it is clear that these are the ice-cored spill heaps of supraglacial streams (Fig. I6). The largest of these rises $8 \mathrm{~m}$ above the rest of the moraine and is opposite the large glacier melt stream that almost certainly deposited the debris. In the first $100 \mathrm{~m}$ from the ice front, recent morainic material completely masks the old surface, but in the outer $40 \mathrm{~m}$ the old surface with growing saxifrage and willow shows through in gaps in the moraine cover. This vegetation appears to have been continuous since before the moraine was formed; only part of it has been destroyed by large erratic boulders rolling and sliding off the steep terminal ice ramp. Some of the erratics are $8 \mathrm{~m}^{3}$ or more in size, and most are of yellow Triassic sandstone. Between 30 and $100 \mathrm{~m}$ from the ice front a few Arctic poppies and mosses have succeeded in colonizing since the recession of the ice.

Similar terminal recession is typical of the side glaciers in the area. Because of the virtual absence of lichens and the very sparse colonization by flowering plants and mosses between the ice ramps and the moraine edges, it is concluded that the ground has been uncovered within the last few decades. The undifferentiated nature of the till outside the moraines suggests that recession took place after a prolonged period of glacier advance and terminal stability. It has been suggested that mean summer temperatures may have been $\mathrm{I}$ to $2^{\circ} \mathrm{C}$ higher in the period I $925-6 \mathrm{I}$, for deep-pit and firn-core studies at an elevation of $\mathrm{I} 800 \mathrm{~m}$ on the central ice cap of northern Ellesmere Island show a much greater frequency and significance of ice layers in the firn stratigraphy of this period than for many previous decades (Hattersley-Smith, 1963). Insolation effects are great, and ablation is consequently very high, on the steep terminal ramps of the smaller glaciers (Adams, I966). These terminal areas are therefore particularly susceptible to small mean temperature changes in the months of July and August. In particular, such changes in temperature can determine whether precipitation falls as snow which inhibits ablation or as rain which greatly promotes ablation. It seems reasonable therefore to 
conclude that the recession of these glaciers from their terminal moraines has occurred since about 1925. This situation could easily be reversed, and indeed there is evidence from pit studies on the central ice cap in 1967 that the summers $1963-66$ have been the coolest sequence of summers since before 1925 , since the firn stratigraphy shows only minor melt features. In this period the ice caps on the plateau south of Tanquary Fiord have extended their margins, with taryn ice forming below valley tongues. In 1964 , for example, the snow line in mid-August on the plateau was at about $85^{\circ} \mathrm{m}$, whereas in 1959 air photographs in late summer show that the entire small ice cap io $\mathrm{km}$ south-east of Tanquary Camp, rising to a maximum elevation of I $220 \mathrm{~m}$, was an ablation area, and that the snow line on the very much larger ice cap, $2 \mathrm{~km}$ farther to the south-east, was at an elevation of at least $1250 \mathrm{~m}$. It is thought that such relatively small changes in summer temperatures, if continued over a number of years, would

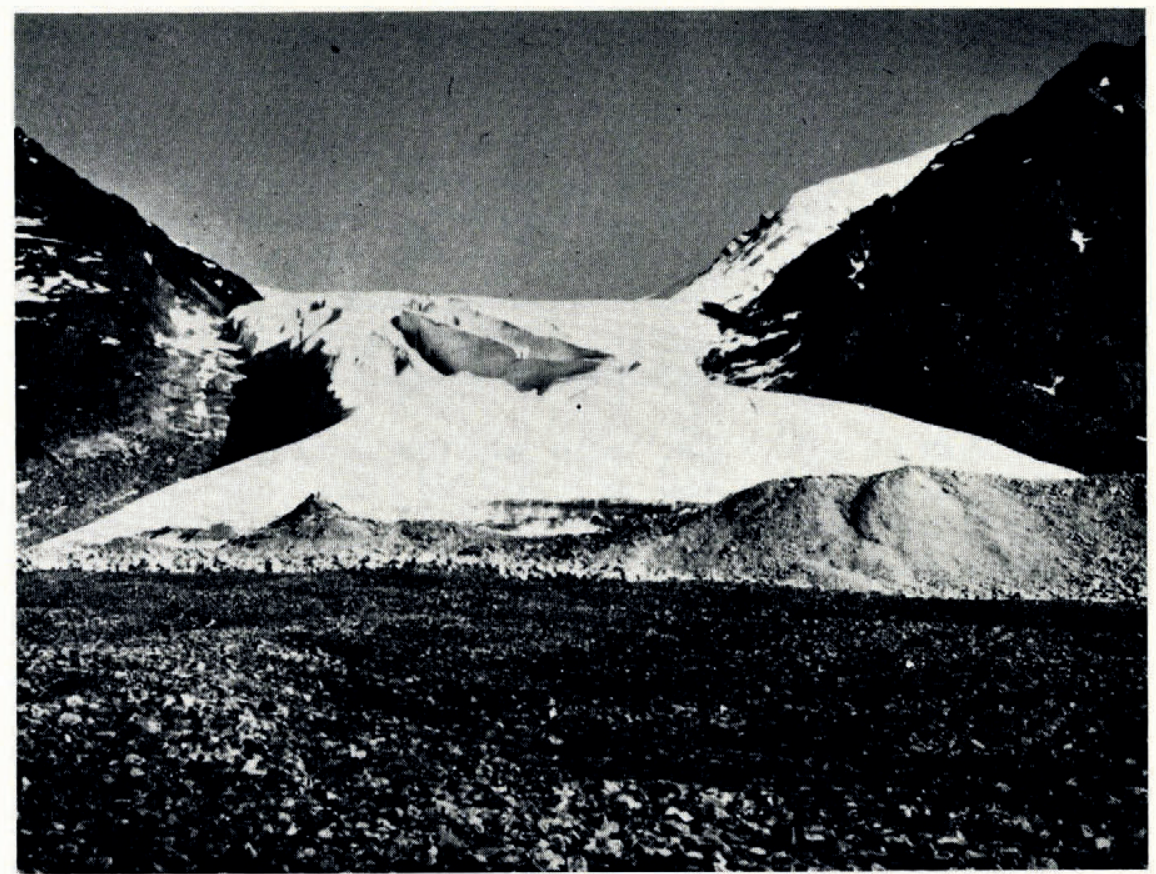

Fig. I6. Tumblerock Glacier showing moraine, 5 July 1963.

cause wide extension of these ice caps. If it is correct that Climatic Optimum mean temperatures, at least in mid-latitudes, were $2.5^{\circ} \mathrm{C}$ higher than at present (Fairbridge, 1967), it is likely that these ice caps have grown up in the last 4000 years or in a much shorter period, as have the Meighen Ice Cap (Arnold, 1965) and the ice shelves and low ice caps of the north coast of Ellesmere Island (Hattersley-Smith, r96r[a]).

\section{Summary and Conclusions}

Some of the main glacial features of Tanquary Fiord and adjoining areas have been discussed. Conclusions may be summarized as follows:

I. Bathymetric data now available give some idea of the morphology of the fiords of north-western Ellesmere Island. Over-deepening is ascribed to glacial erosion which greatly modified the ancestral river system. 
2. The four valleys about the head of Tanquary Fiord have seen the passage of great thicknesses of ice. Although the Tanquary Fiord area has been inundated by ice in the past, periods of alpine glaciation were long enough to produce well-developed cirques.

3. Fluvial erosion in this so-called "desert" climate should not be underestimated, because the snow and glacial run-off is concentrated in a period of little more than 2 months. In fact, a long period of fluvial erosion has intervened since the last total occupation of the valleys by ice, as shown by the entrenched rivers of main valleys, and by the V-shaped valleys below minor tributary glaciers. Later re-occupation of the $\mathrm{V}$-shaped valleys is inferred.

4. High-level moraines, glacial drift, erratics and striae testify to the former very widespread ice cover of the area. But it is not known to what extent these features date from the Wisconsin or from some earlier period. However, the age of peat deposits in the valleys and the age of raised beaches show that the extensive delta terraces were formed by melt streams from waning Wisconsin ice caps, which were massive enough to cause depression of the land by at least $60 \mathrm{~m}$.

5. Glacial lakes, several of large size, are conspicuous features of the area, and the varved deposits of former glacial lakes occur in various places. The mechanism of periodic drainage of the present lakes is not fully understood but it may be cyclic and relatively independent of climate. On the other hand, it may be related to the recent recession of the side glaciers from terminal moraines. Drainage is often catastrophic and very destructive of glacial deposits down-stream.

6. The major glaciers of the area appear close to their maximum extent of at least the last 900 years and probably of a much longer period; they may be advancing slightly. On the other hand, recent looped moraines off all the side glaciers seen in the area are believed to be due to glacial retreat since about 1925 , as inferred from glaciological studies on the central ice cap of northern Ellesmere Island.

\section{AcKNowledgements}

Grateful acknowledgement is made to Dr J. G. Fyles, of the Geological Survey of Canada, who kindly arranged for radiocarbon analyses of three samples (GSC-373, 374, 376), and to members of Defence Research Board field parties, especially Messrs H. Serson, N. E. Cleary and U. Embacher, for assistance in the field.

MS. received 9 May 1968

\section{POSTSCRIPT}

Radiocarbon analyses of bottom material from Lake Tuborg, Ekblaw and Rollrock Lakes giving ages of $2125^{\circ}$ to $2665^{\circ}$ years B.P. (SI-570, 571, 572; Mielke and Long, in press), together with recent botanical discoveries in northern Ellesmere Island (personal communication from G. R. Brassard), suggest that maximum glaciation of the fiords and main valleys pre-dated the Wisconsin period. The amount of river erosion and dissection in the area since the recession of the ice also points to a pre-Wisconsin age for the main glaciation.

\section{December 1968}

\section{REFERENCES}

Adams, W. P. 1966. Glaciology, No. I. Ablation and run-off on the White Glacier, Axel Heiberg Island, Canadian Arctic Archipelago. Axel Heiberg Island Research Reports, McGill University, Montreal. Facobsen-McGill Arctic Research Expedition 1959-1962.

Arnold, K. C. 1965. Aspects of the glaciology of Meighen Island, Northwest Territories, Canada. Journal of Glaciology, Vol. 5, No. 40, p. 399-4 Io.

Bowman, T. E., and Long, A. 1968 . Relict populations of Drepanopus bungei and Limnocalanus macrurus grimaldii (Copepoda: Calanoida) from Ellesmere Island, N.W.T. Arctic, Vol. 21, No. 3, p. 172-8o. 
Christie, R. L. 1963. Tanquary Fiord area. (In Glaciology. Canadian Geophysical Bulletin, Vol. 16, p. I22.)

Christie, R. L. 1967. Reconnaissance of the surficial geology of northeastern Ellesmere Island, Arctic Archipelago. Canada. Geological Survey. Bulletin 138.

Crary, A. P. 1960. Arctic ice island and ice shelf studies. Part II. Arctic, Vol. 13, No. I, p. 32-50.

Crary, A. P., and Goldstein, N. 1957. Geophysical studies in the Arctic Ocean. Deep-Sea Research, Vol. 4, No. 3, p. $185^{-201}$.

De Leeuw, M. M. 1967. New Canadian bathymetric chart of the western Arctic Ocean, north of $72^{\circ}$. Deep-Sea Research, Vol. 14, No. 4, p. 489-504.

Dyck, A., and Fyles, J. G. 1963. Geological Survey of Canada radiocarbon dates. II. Radiocarbon, Vol. 5 , p. $39-55$.

Fairbridge, R. W. 1967. Climatic optimum hypsithermal. (In Fairbridge, R. W., ed. The encyclopedia of atmospheric sciences and astrogeology. New York, Reinhold Publishing Corporation, p. 20I-02.)

Ford, W. L., and Hattersley-Smith, G. 1965. On the oceanography of the Nansen Sound fiord system. Arctic, Vol. 18, No. 3, p. $15^{8}-7$ I.

Fortier, Y. O., and Morley, L. W. 1956. Geological unity of the Arctic islands. Transactions of the Royal Society of Canada, Third Ser., Vol. 5o, Sect. 4, p. $3^{-12 .}$

Fortier, Y. O., and others. 1963 . Geology of the north-central part of the Arctic Archipelago, Northwest Territories (Operation Franklin), by Y. O. Fortier [and ro others]. Canada. Geological Survey. Memoir 320.

Glen, J. W. r 954. The stability of ice-dammed lakes and other water-filled holes in glaciers. Fournal of Glaciology, Vol. 2, No. 15, p. $3^{16-18 .}$

Hattersley-Smith, G. 1960. Some remarks on glaciers and climate in northern Ellesmere Island. Geografiska Annaler, Vol. 42, No. I, p. $45-48$.

Hattersley-Smith, G. I96I[a]. Geomorphological studies in north-western Ellesmere Island. Ottawa, Defence Research Board. (Directorate of Physical Research, Report No. Misc. G-5.)

Hattersley-Smith, G. I961[b]. The ice cover of northern Ellesmere Island. Annals of the New York Academy of Sciences, Vol. 95, Art. 1, p. 282-89.

Hattersley-Smith, G. 1963 . Climatic inferences from firn studies in northern Ellesmere Island. Geografiska Annaler, Vol. 45, Nos. 2-3, p. 139-5I.

Hattersley-Smith, G. I964. Rapid advance of glacier in northern Ellesmere Island. Nature, Vol. 201, No. 4915, p. 176.

Hattersley-Smith, G., and Long, A. 1967. Postglacial uplift at Tanquary Fiord, northern Ellesmere Island, Northwest Territories. Arctic, Vol. 20, No. 4, p. 255-60.

Hattersley-Smith, G., and Serson, H. r964. Stratified water of a glacial lake in northern Ellesmere Island. Arctic, Vol. 17, No. 2, p. 108-i I.

Helk, J. V. r966. Glacier mapping in Greenland. Canadian Journal of Earth Sciences, Vol. 3, No. 6, p. 77 I-74.

Konecny, G. 1966. Applications of photogrammetry to surveys of glaciers in Canada and Alaska. Canadian Journal of Earth Sciences, Vol. 3, No. 6, p. $783-98$.

Langway, C. C. 1967 . Stratigraphic analysis of a deep ice core from Greenland. U.S. Cold Regions Research and Engineering Laboratory. Research Report 77.

Long, A. 1967. Age of trapped sea-water at bottom of Lake Tuborg, Ellesmere Island, N.W.T. Transactions. American Geophysical Union, Vol. 48, No. 1, p. 136.

Lowdon, J. A., and others. I967. Geological Survey of Canada radiocarbon dates. VI, by J. A. Lowdon, J. G. Fyles and W. Blake. Radiocarbon, Vol. 9, p. ${ }_{156}^{6}-97$.

Lyons, J. B., and Leavitt, F. G. 1961. Structural and stratigraphic studies on the Ward Hunt Ice Shelf. Bedford, Mass., Gəophysics Research Directorate, U.S. Air Force Cambridge Research Laboratories. (Final report on Contract AF rg(604)-6r88.)

Maag, H. U. Unpublished. Ice-dammed lakes in Axel Heiberg Island, Canadian Arctic Archipelago. [Paper read at Union Géodésique et Géophysique Internationale. Association Internationale d' Hydrologie Scientifique. Assemblée générale de Berne, r967. Commission de Neiges et Glaces.]

Mielke, J. E., and Long, A. In press. Smithsonian Institution radiocarbon measurements, V. Radiocarbon, Vol. $1 \mathrm{I}$.

Nassichuk, W. W., and Christie, R. L. In press. Upper Palaeozoic and Mesozoic stratigraphy between Yelverton Pass and Tanquary Fiord, Ellesmere Island. Canada. Geological Survey. Paper.

Pelletier, B. R. 1966. Development of submarine physiography in the Canadian Arctic and its relation to crustal movements. (In Garland, G. D., ed. Continental drift. [Toronto], University of Toronto Press in co-operation with the Royal Society of Canada, p. 77-ror. (Royal Society of Canada. Special Publications, No. 9.))

Radforth, N. W. 1965. Muskeg in Arctic North America. Nature, Vol. 205, No. 4977, p. I $153-55$.

Rudberg, S. I963. Morphological processes and slope development in Axel Heiberg Island, Northwest Territories, Canada. Nachrichten der Akademie der Wissenschaften in Göttingen, 2. Mathematische-physikalische Klasse, Jahrg. 1963, Nr. 14, p. $211-28$.

Smith, D. I. $196 \mathrm{r}$. The glaciation of northern Ellesmere Island. Folia Geographica Danica, Tom. 9, p. 224-34.

Thorsteinsson, R., and Tozer, E. T. I 960 . Summary account of structural history of the Canadian Arctic Archipelago since Precambrian time. Canada. Geological Survey. Paper 6o-7.

Trautman, M. A. I963. Isotopes Inc. radiocarbon measurements. III. Radiocarbon, Vol. 5, p. 67-79.

Troelsen, J. C. 1952. Geological investigations in Ellesmere Island, 1952. Arctic, Vol. 5, No. 4, p. 199-2 10.

Weidick, A. 1963. Ice margin features in the Julianehåb district, south Greenland. Meddelelser om Grønland, Bd. 165, Nr. 3 . 